\title{
Effects of eliminating the triacylglycerols structure of bulk oils on the antioxidant performance of $\gamma$-oryzanol: A kinetic and thermodynamic study
}

\author{
Mohamad Reza Toorani ${ }^{1}$ and Mohammad-Taghi Golmakani ${ }^{2}$ \\ ${ }^{1}$ Ferdowsi University of Mashhad \\ ${ }^{2}$ Shiraz University
}

August 3, 2020

\begin{abstract}
In this study, the effect of triacylglycerol structure on the performance of $\gamma$-oryzanol was evaluated. For this purpose, the kinetic parameters of pure triacylglycerols and fatty acid methyl esters of olive, sesame, corn, sunflower, and soybean oils were calculated in the presence $\gamma$-oryzanol at 60,70 , and $80{ }^{\circ} \mathrm{C}$. The obtained results showed that $\gamma$-oryzanol was more effective in improving the induction period and the level of hydroperoxides production in fatty acid methyl ester systems in comparison to the triacylglycerol ones. An increase in the temperature led to higher participation of $\gamma$-oryzanol in undesirable side reactions. The participation rate in these reactions was higher in the higher $\gamma$-oryzanol efficiency systems. In the inhibited oxidation reactions, eliminating the triacylglycerols structure of oils caused a considerable increase in all Arrhenius and Eyring model parameters. These findings revealed that the antioxidant activity of $\gamma$-oryzanol was increased by the destruction of the triacylglycerol structure.
\end{abstract}

\section{Introduction}

Oxidation of lipids begins with the invasion of free radicals to the unsaturated fatty acids and then enters to the accelerated phase by involving the oxygen molecules. This reaction can threaten a consumer's health by producing harmful products (Sanders, 1989; Frankel, 1998; Shahidi, 2005). The oxidation reaction is influenced by the temperature of the environment that this process frequently is described by the Arrhenius equation (Shim and lee, 2011; Farhoosh and Hoseini-Yazdi, 2014; Veloso et al., 2020). This equation is a part of the transition theory stating the effective collisions with the specified level of energy should be occurred between the reactant molecules for initiating a chemical reaction (Atkins and De Paula, 2006). In parallel to this theory, the plant's metabolic systems employ a clever defensive mechanism in the face of lipids oxidation by locating the more unsaturated fatty acids in the middle position of triacylglycerol (TAG) molecules. This phenomenon reduces the effective collisions of oxidizing agents with the oxidation active sites (Shahidi, 2005). Indeed, this mechanism shows its effects by creating a steric hindrance.

The addition of antioxidants is one of the most important approaches to retard the lipids oxidation reaction. $\gamma$-oryzanol is a natural lipophilic antioxidant consisted of a mixture of phytosteryl ferulate as shown in Fig. 1 $(\mathrm{Xu}$ and Godber, 1999). Like other antioxidants, the antioxidant activity of $\gamma$-oryzanol depends on two main mechanisms, i.e. electron transferring and hydrogen-donating (Toorani et al., 2020). In these mechanisms, intimate interaction between the active agent of antioxidant (hydroxyl group) and the double bond of fatty acids is required. The steric prevention caused by the TAG structure may have an inhibitory effect on the antioxidants performance, in other words, the TAGs structure can reduce the number of effective collisions between antioxidant molecules and the formed radicals on the fatty acid chain. 
Considering lack of experimental data in the literature, the aim of the present study was estimating kinetic and thermodynamic parameters of $\gamma$-oryzanol in the presence of TAGs and fatty acid methyl esters (FAMEs) of olive, sesame, corn, sunflower, and soybean oils at different temperatures to explain the possible effects of the TAG structure on $\gamma$-oryzanol performance.

\section{Materials and Methods}

\section{Materials}

Refined olive, sesame, corn, sunflower, and soybean oils with no antioxidant additive were supplied. The $\gamma$ oryzanol was purchased from Tokyo Chemical Industry (TCI CO, Tokyo, Japan). All other used analytical grade chemicals and standard markers were supplied from Sigma Aldrich (St. Louis, MO) and Merck (Darmstadt, Germany).

\section{Preparation of FAME}

The FAMEs were prepared according to the described method by Toorani et al. (2019). Methanol: oil (molar ratio of $6: 1)$ and sodium methoxide $(0.5 \%, \mathrm{w} / \mathrm{w})$ was used as catalyst and reactant, respectively. The reactant and catalyst were thoroughly mixed using a hot plate stirrer for $5 \mathrm{~min}$ at $60{ }^{\circ} \mathrm{C}$. The oil was then added slowly to the mixture and the methylation process was completed for $45 \mathrm{~min}$ at a controlled temperature. The prepared mixture was transferred to a separatory funnel for $24 \mathrm{~h}$ to the differentiation FAMEs from glycerol. Thereafter, the FAMEs were filtered to decrease the catalyst amount and remove the possible suspended glycerols. Methanol was removed by vacuum rotary evaporator that the temperature of the hot water bath was regulated at $60{ }^{\circ} \mathrm{C}$. The FAMEs were transferred to a glass column with a stopcock plug and the catalyst was gradually removed using distilled water. This continued until the full transparency of FAMEs. Finally, the added water was removed in a vacuum rotary evaporator at $60{ }^{\circ} \mathrm{C}$.

\section{Purification of the oils and FAMEs}

Minor components can affect the oxidation reactions or $\gamma$-oryzanol performance. Therefore, purification of different oils and also their FAMEs was carried out by adsorption chromatography column without any solvent. Briefly, two glass column series $(36 \mathrm{~cm}$ height and $2.9 \mathrm{~cm}$ internal diameter) were used. Each column was composed of three-layer adsorbents including $5 \mathrm{~g}$ of activated carbon, $30 \mathrm{~g}$ of silica gel, and 50 $\mathrm{g}$ of aluminum oxide 60 (from top to bottom). All sorbents were activated at $180{ }^{\circ} \mathrm{C}$ for $4 \mathrm{~h} .120 \mathrm{~g}$ of each oil was gradually added to the first column. A vacuum pump was used to facilitate the oil flow through the chromatography column. The first column output was transferred to the second one and then the previous cycle was repeated. The purified samples were maintained at $-18{ }^{\circ} \mathrm{C}$ for a maximum of two weeks and the headspace was filled up with nitrogen gas (Toorani et al., 2019).

\section{Fatty Acids Composition}

The fatty acids profile of different oils was identified using a gas chromatography device (Hewlett-Packard, 5890, Palo Alto, CA) according to the AOCS method (2009). Eq. 1 was used to Cox value (calculated oxidizability $\mathrm{x}$ ) as a general symbol of the stability of the oils (Fatemi and Hammond, 1980):

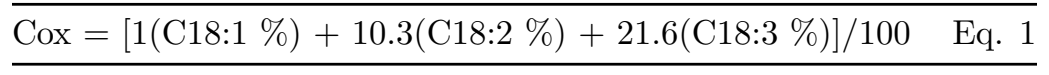

\section{Peroxidation of lipid systems}

The peroxidation process of the lipid systems was carried out through the estimation of hydroperoxides $(\mathrm{LOOH})$ accumulation overtime at 60,70 , and $80{ }^{\circ} \mathrm{C}$ in a dry oven. For this propose, $6 \mathrm{~g}$ of TAGs and FAMEs of olive, sesame, corn, sunflower, and soybean oils containing $(0.08 \%$ or $13.28 \mathrm{mM})$ and without $\gamma$ oryzanol were added to the separate Petri dishes. It's proven that the beyond mentioned amount, the linear relationship between increasing concentration and antioxidant activity of $\gamma$-oryzanol will be lost (Toorani et al., 2020). The drawing kinetic curve was used to calculate the antioxidant activity of $\gamma$-oryzanol based on $\mathrm{LOOH}$ production during the time. 


\section{The LOOH measurement}

The accumulation of LOOH was measured according to Shanta and Decker (1994) method. 9.8 mL chloroform/methanol $(7 / 3, \mathrm{v} / \mathrm{v})$ was added to the oil sample $(0.001-0.3 \mathrm{~g})$ in a test tube. Then, $50 \mu \mathrm{L}$ ammonium thiocyanate aqueous solution $(30 \%, \mathrm{w} / \mathrm{v})$ was added and the mixture was vortexed for $4 \mathrm{~s} .50 \mu \mathrm{L}$ of $\mathrm{FeCl}_{2}$ solution was added to the test tube and the solution was shaken completely for $4 \mathrm{~s}$. Finally, its absorbance was read at $500 \mathrm{~nm}$ (against a blank sample) after 5 min incubation at room temperature.

\section{Kinetic parameters}

In the initiation stage of lipid oxidation, the reaction rate is independent of the concentration of the reactants. It can be described by a zero-order reaction (Eq. 2):

$$
\overline{\left(\frac{d[L O O H]}{\mathrm{dt}}\right)=k \quad \text { Eq. } 2}
$$

where $k$ is oxidation rate constant. By integrating Eq. 2 vs. the limited time from $t_{0}=0$ to $t=I P$ (IP: induction period) (Fig. 2) and a concentration range from $[\mathrm{LOOH}]_{0}$ (the amount of hydroperoxides in zero time) to $[\mathrm{LOOH}]_{\mathrm{IP}}$ (the amount of produced hydroperoxides at IP point), the Eq. 3 is obtained:

$$
\overline{\int_{[L O O H]_{0}}^{[L O O H]_{\mathrm{IP}}} d[L O O H]=k \int_{0}^{\mathrm{IP}} \mathrm{dt} \rightarrow[L O O H]_{\mathrm{IP}}=[L O O H]_{0}+k \mathrm{IP} \quad \text { Eq. } 3}
$$

The zero-order rate constant $\left(\mathrm{mol} \mathrm{L} \mathrm{L}^{-1} \mathrm{~s}^{-1}\right)$ will be obtained (Eq. 4) by considering $[\mathrm{LOOH}]_{0}$ equals to zero:

$$
\overline{k=\left(\frac{[L O O H]_{\mathrm{IP}}}{\mathrm{IP}}\right) \quad \text { Eq. } 4}
$$

According to Eq. 5 (Arrhenius equation), the activation energy $\left(E_{\text {a }}\right)$ and frequency factor $(A)$ of the production of $\mathrm{LOOH}$ were calculated by plotting the natural logarithm of $k$ vs. the $1 / R \mathrm{~T}$ :

$$
\overline{\ln k=-\left(\frac{E_{a}}{R T}\right)+\ln A \quad \text { Eq. } 5}
$$

where $R$ and $\mathrm{T}$ represent the molar gas constant $(8.3143 \mathrm{~J} / \mathrm{mol} \mathrm{K})$ and temperature $(\mathrm{K})$, respectively.

According to Eq. 6, the Arrhenius equation parameters were calculated using the obtained slope (a) and intercept (b) from Eq. 5:

$$
\begin{array}{ll}
\hline E_{a}=-a & \text { Eq. } 6 \\
\hline A=\exp (b) & \text { Eq. } 7 \\
\hline
\end{array}
$$

Enthalpy $\left(\Delta \mathrm{H}^{++}\right)$and entropy $\left(\Delta \mathrm{S}^{++}\right)$of activation were determined by the Eyring equation via drawing $\ln (k / \mathrm{T})$ against $(1 / R \mathrm{~T})$ :

$$
\overline{\ln \left(\frac{k}{T}\right)=\ln \left(\frac{k_{B}}{h}\right)+\left(\frac{\Delta S^{++}}{R}\right)-\left(\frac{\Delta H^{++}}{R T}\right) \quad \text { Eq. } 8}
$$

where $k_{\mathrm{B}}$ and $h$ are the Boltzmann constant $\left(1.380658 \times 10^{-23} \mathrm{~J} \mathrm{~K}^{-1}\right)$ and Planck's constant $(6.6260755 \times$ $\left.10^{-34} \mathrm{~J} \mathrm{~s}\right)$, respectively. The values of enthalpy and entropy were calculated using the slope and intercept 
(Eq. 9):

\begin{tabular}{ll}
\hline$\Delta H^{++}=-a$ & Eq. 9 \\
\hline$\Delta S^{++}=\left[b-\ln \left(\frac{k_{B}}{h}\right)\right] \times R$ & Eq. 10 \\
\hline
\end{tabular}

The calculated enthalpy and entropy were used to determine the Gibbs free energy (Eq. 11):

$\overline{\Delta G^{++}=\Delta H^{++}-T \Delta S^{++} \quad \text { Eq. } 11}$

The effect of temperature on $\gamma$-oryzanol effectiveness was described using Eq. 12:

$$
\overline{\Delta k=k_{\mathrm{Con}}-k_{\mathrm{AH}} \quad \text { Eq. } 12}
$$

where the $\Delta k$ is the difference between in the non-inhibited (in the absence $\gamma$-oryzanol, $k_{\text {con }}$ ) and inhibited $\left(k_{A H}\right)$ oxidation in the presence of $\gamma$-oryzanol. By linear regression between the natural logarithm of $\Delta k$ and temperature, decrease in the effectiveness of $\gamma$-oryzanol $\left(\mathrm{Ef}_{\mathrm{d}}\right)$ by a $10{ }^{\circ} \mathrm{C}$ increase in the temperature was calculated from the slope (a) of the mentioned relationship (Eq. 13):

$$
\overline{\mathrm{Ef}_{d}=\exp (10 a) \quad \text { Eq. } 13}
$$

\section{Statistical analysis}

All determinations were performed in triplicate and the results were analyzed by one way ANOVA. Statistical and regression analyses were performed using SPSS and Excel software. Significant differences among means were compared by the post-hoc multiple ranges of Duncan's test ( $P$-value [?] 0.05).

\section{Results and Discussion}

\section{Fatty acids composition of the oil}

Table 1 shows the fatty acid profiles of the oils. It can be observed that the type of oils can be distinguished considering the differences in their SFA, MUFA, and PUFA contents. The olive oil, soybean oil and sesame oil contained the highest amounts of MUFA (64.2\%), PUFA (65.2\%) and SFA (20.5\%), respectively. It was found that the sunflower and corn oils contained the highest amounts of linoleic acid. Since, the oxidation rate of oleic acid is 12 and 25 times lower than of dienoic and trienoic homologous series, respectively (Hsieh and Kinsella, 1989). It was expected that $\gamma$-oryzanol acts differently in these lipid systems. Based on the COX index, the olive oil showed the highest oxidative stability followed by sesame oil, corn oil, sunflower oil and soybean oil.

\section{Revision on the calculation method of the rate constant}

Monitoring the primary oxidation indices is known as one of the most common methods for evaluating antioxidants activity. The presence of an antioxidant can significantly change the rate constant of $\mathrm{LOOH}$ production, which is widely used in estimating the effectiveness of the antioxidant. One of the critical points is related to the rate constant calculation considering the reaction order. The rate constant is usually considered as the IP reciprocal. This calculation method has a very important limitation as shown in Fig. 2. In some cases, the IPs of some oils could be similar while the slopes of LOOH production are not identical (graph 1 and 2 in Fig. 2). Hence, the oils with different oxidation resistance have the same rate constant in most cases which normally observed in the graphs of the Rancimat test. For instance, Farhoosh et al., (2008) reported that the $E$ a of soybean oil was higher than the olive oil, though it is obvious that the 
soybean oil has lower oxidation stability compared to olive oil. In another study, the $E$ a for linseed oil (without antioxidant) was higher than linseed oil containing TBHQ (Golmakani et al., 2020). Nevertheless, the question that arises here is - how may the $E_{\text {a }}$ of a lipid system with lower oxidation resistance be higher than that of a lipid system with higher resistance? Although, there are many problems in calculating the kinetic and thermodynamic data of oils, which Dijkstra (2017) has pointed out some of them.

The rate constant also could be estimated using the slope of the fitted line in the initiation stage of oxidation; however, this calculation method shows a noticeable weakness. In some cases, the slope of the fitted line of two different oxidative systems could be similar while their IPs are completely different (graph 3 and 4 in Fig. 2 ). This frequently occurs as the concentration of an antioxidant increases in a certain lipid system. These kinds of problems are generally related to the applied method in calculating the constant rate. To overcome the mentioned problems, the best solution is using the slope $\left(\mathrm{LOOH}_{\mathrm{IP}}\right.$ : as a measure for introducing the slope) and IP simultaneously (according to Eq. 4).

\section{Evaluating the changes in IP and LOOH $_{I P}$}

Fig. 3 represents the relationship between the length of IP and the amount of LOOH generated at the IP point of various lipid systems at different temperatures. In high stable lipid systems, the $\mathrm{LOOH}_{\mathrm{IP}}$ was lower than the less stable ones; for example, the $\mathrm{LOOH}_{\mathrm{IP}}$ for TAG of olive oil (in the presence of $\gamma$-oryzanol at $60{ }^{\circ} \mathrm{C}$ ) was $14.5 \mathrm{meq} \mathrm{kg}^{-1}$, while that was 32.5 for soybean oil. The length of IP in lipid systems with high resistance (such as olive oil) was also higher than the soybean oil (27.8 vs. 11.2 hours); therefore, the calculated rate constant (using Eq. 4) for the oxidation-resistant systems was smaller. Similarly, the calculated rate constant of less stable systems would be higher because of having the lower IP and higher $\mathrm{LOOH}_{\mathrm{IP}}$. It was also observed that the slope of the fitted correlation line between $\mathrm{LOOH}_{\mathrm{IP}}$ and IP was higher in the less stable systems due to the decrease in the $\mathrm{LOOH}_{I P}$ at higher temperatures (Fig. 3). These results indicate that the $\mathrm{LOOH}_{\mathrm{IP}}$ in such systems is more thermally affected. In the same way, Shim and Lee (2011) observed a decrease in $\mathrm{LOOH}_{\mathrm{IP}}$ at a higher temperature. Another important point about the effect of temperature is related to the decrease in the IP length in the presence of $\gamma$-oryzanol in comparison to the control samples, which is called the stabilization factor $(F)$ :

$$
\overline{F=\frac{\mathrm{IP}_{\mathrm{AH}}}{\mathrm{IP}_{\mathrm{Con}}}} \text { eq. (14) }
$$

A decrease in the $F$ parameter demonstrates the participation of antioxidant molecules in the undesirable side reactions of oxidation (Marinova and Yanishlieva, 2009; Toorani et al., 2020). As shown in Fig. 4 and regarding the slope of the fitted line on the temperature dependence of the $F$ parameter, the highest amount of $\gamma$-oryzanol participation in the oxidation side reactions was related to the sunflower oil FAMEs with the highest possible slope. The referred side reactions are shown as Eqs. 15 to 17:

\begin{tabular}{ll}
\hline $\mathrm{AH}+\mathrm{LOO}^{*} \mathrm{LOOH}+\mathrm{A}^{*}$ & Eq. 15 \\
\hline $\mathrm{AH}+\mathrm{LOOH} \mathrm{A}^{*}+\mathrm{LO}^{*}+\mathrm{H}_{2} \mathrm{O}$ & Eq. 16 \\
$\mathrm{AH}+\mathrm{O}_{2} \mathrm{~A}^{*}+\mathrm{HOO}^{*}$ & Eq. 17 \\
\hline
\end{tabular}

Considering the decrease in the $F$ parameter with increasing temperature, it can be concluded that $\gamma$ oryzanol in all studied lipid systems participated in the mentioned reactions at a higher temperature (Fig. 4). However, the systems with the highest $\gamma$-oryzanol efficiency showed a greater reaction participation rate.

\section{Analysis of rate constant and Arrhenius equation parameters}

The rate constant of studied lipid systems at different temperature are listed in Table 2 . In all samples, the rates constant of non-inhibited FAMEs $\left(\mathrm{FAME}_{\mathrm{Con}}\right)$ were higher than the non-inhibited TAGs $\left(\mathrm{TAG}_{\mathrm{Con}}\right)$. This revealed that the elimination of the TAG structure increased the oxidation reaction rate. In all samples, 


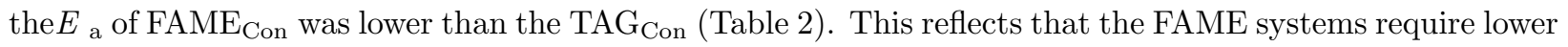
energy to produce $\mathrm{LOOH}$. This result can be attributed to the reduction of the medium viscosity and thus increasing the oxygen emission (Kahl and Hildebrandt, 1986), or due to the higher effective collision between oxidant agents and oxidative site via removing the steric hindrance of TAG structure (Shahidi, 2005). As expected, the addition of $\gamma$-oryzanol to all lipid systems significantly reduced the oxidation rate constant (Table 2). This reduction was higher in FAMEs systems indicating an increase in the antioxidant activity of $\gamma$-oryzanol by eliminating the TAG structure. The high efficiency of $\gamma$-oryzanol in FAME systems can be demonstrated considering the $E_{\text {a }}$, which was statistically higher compared to its corresponding systems, i.e. TAGs. In agreement with the findings in the present study, there are some reports about evaluating the effect of TAG structure on the antioxidants performance (Marinova and Yanishlieva, 1995; Toorani et al., 2019). Since, the amount of $\mathrm{LOOH}$ accumulation is considered in the calculation of Arrhenius equation parameters, it is obvious that increasing the indices of this equation is a response to the reduction of the oxidation rate. In fact, the difference of the $\gamma$-oryzanol performance caused by the destruction of TAG structure could be related to the reduction in the collisions of free radicals to induce the oxidation process. This collisions reduction may be arising from an increase in the effective collisions between the antioxidant active agent $(-\mathrm{OH})$ and oxidized sites (the formed radical on double bonds of fatty acids). In other words, the rate of interactions between the oxidation active radicals has been reduced due to increasing the chance of effective collisions between $\gamma$-oryzanol molecules and peroxyl radicals by removing TAG structure.

" $A$ " is another parameter of the Arrhenius equation representing a similar trend with the $E$ a. There is a relationship between parameters of $A$ and $\Delta S^{++}$as shown in Eq. 18.

$$
\overline{A=\exp \left(\frac{\Delta S^{++}}{R}\right) \times\left(\frac{k_{B} T}{h}\right) \quad \text { Eq. } 18}
$$

Considering the constant parameters $\left(R, k_{B}, \mathrm{~T}\right.$, and $\left.h\right)$ in Eq. 18, it can be concluded that the changes of $A$ and $\Delta S^{++}$are quite related to each other. The values of Eyring equation parameters for the studied lipid systems are shown in Table 3. The Eyring equation represents the activation complex theory stating that an intermediate complex is required to produce the products in a chemical reaction. For instance, in a lipid system, a high level of energy is needed to form an activated complex. This energy is spent to change the length and bond angles of reactants resulting in the rearrangement and structural integrity of the oxidative substrates. In general, the concentration and decomposition rate of activated complex, known as effective factors on the oxidation rate, are evaluated based on the enthalpy and entropy changes (Atkins and De Paula, 2006; Farhoosh, 2018). However, a lipid system with higher $\Delta H^{++}$or lower $\Delta S^{++}$will have a high oxidation resistance. The obtained results indicate the almost similar pattern in the changes of $\Delta H^{++}$and $E$ a (Tables 2 and 3). Therefore, it can be concluded that these two parameters were almost equal. However, the $\Delta S^{++}$changes showed a different trend in comparison to the $\Delta H^{++}$. For example, the collapse of the TAG structure caused a decrease in $\Delta S^{++}$in all lipid systems without $\gamma$-oryzanol. This means reducing disorder in the lipid medium, resulting a decrease in the LOOH production. However, the obtained results were completely different in the presence of $\gamma$-oryzanol. It means that the higher environmental disorder (as a result of increasing $\Delta S^{++}$) caused an increase in the number of engaged molecules in the formation of the activated complex.

Fig. 5 shows the effect $\gamma$-oryzanol on $E$ a and $\Delta S^{++}$of different lipid systems. The effect of $\gamma$-oryzanol on the variation of $E$ a and $\Delta S^{++}$was higher in the FAME systems than TAGs ones. As, the highest and the lowest alterations in $E$ a were observed in the FAMEs of sunflower oil (containing the highest amount of linoleic acid) and TAGs of soybean oil (containing the highest amount of linolenic acid), respectively. The same trends also were observed about $\Delta S^{++}$. Fig. 6a represents the percentage of caused changes in the studied lipid systems by $\gamma$-oryzanol on the $E$ a and $\Delta S^{++}$. Approximately, in the presence of the $\gamma$-oryzanol, a minimum of $15 \%$ and a maximum of $40 \%$ were added to the values of $\Delta S^{++}$and $E$ a, respectively. It is indicating the power of antioxidant in the used concentration.

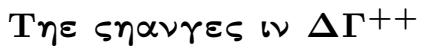


It is proven that the parameters of Arrhenius or Eyring equations are lonely unable to predict the stability of a lipid system (Farhoosh, 2018). However, $\Delta G^{++}$is suitable for comparing the oxidative stability of the oils. At a certain temperature, the higher value of $\Delta G^{++}$indicated the higher oxidative stability of a lipid system (Farhoosh and Hoseini-Yazdi, 2014). In the absence of $\gamma$-oryzanol, the $\Delta G^{++}$of all the studied oils were lower in FAMEs rather than the TAGs, while that this trend was completely different in the presence of $\gamma$-oryzanol (Table 3). These results indicated that in the non-inhibited oxidation, the removal of the TAG structure reduced the oxidation resistance of the oils. However, the destruction of the TAG structure improved the antioxidant activity of $\gamma$-oryzanol during the inhibited oxidation. The effects of this better performance can be observed in the difference between $\Delta G^{++}$values of TAG and FAME systems. Fig $6 \mathrm{~b}$ shows the percentage increase in the $\Delta G^{++}$for all lipid systems due to the presence of $\gamma$-oryzanol. The best $\gamma$-oryzanol performance was found in the FAME of sunflower and corn oils, but its efficiency decreased at higher temperatures. However, this temperature dependence followed with a lenient slope in the more stable systems such as olive oil.

The changes in $\Delta G^{++}$at different temperatures indicated a decrease in the dispersion of the data with the collapse of the TAG structure (Fig. 7a). The lack of outlier data reflected the accuracy of the calculations and the normality of data. As shown in Fig. 7b, the size of the box plots of TAG and FAME systems were similar. It means that in all studied oils, the same improvement in the effectiveness of $\gamma$-oryzanol was observed because of TAG structure destruction. Besides, the distribution of data (represented by dash lines) in TAG systems was more than FAME systems. This can be attributed to the high inhibitory effect of the TAG structure of some oils on the $\gamma$-oryzanol performance.

A linear relationship was found between the values of $\Delta G^{++}$and the length of the IP which can be used in predicting the $\Delta G^{++}$through simple data such as IP (Fig. 8). Thus, the obtained equations could be used to the estimation and comparison of the oxidative stability of the lipid systems. Fig. 9 shows the percentage increase in the kinetic and thermodynamic parameters due to the presence of $\gamma$-oryzanol. The considerable effect of $\gamma$-oryzanol was related to the $A$ parameter due to the removal of the TAG structure. Also, the changes in the other parameters represent a difference in the behavioral pattern of $\gamma$-oryzanol with the destruction of the TAG structure, which originated from the steric hindrance of the TAG structure.

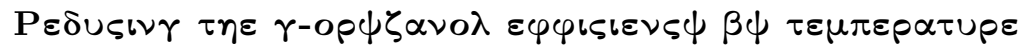

The rate of $\mathrm{LOOH}$ production indirectly represented that $\gamma$-oryzanol efficiency $\left(\mathrm{Ef}_{\mathrm{d}}\right)$ reduced as the temperature increased (Table 3). The values of $\mathrm{Ef}_{\mathrm{d}}$ changed from 1.79 to $2.01 \mathrm{in}$ different lipid systems. There was no significant difference between $\mathrm{Ef}_{\mathrm{d}}$ of $\mathrm{TAG}$ and FAME systems $(P>0.05)$. A linear regression model was developed between Efd and Cox values of different systems (Fig. 10). The systems with high oxidation-resistant showed a higher decrease in $\gamma$-oryzanol efficiency by increasing temperature.

\section{Conclusion}

In this study, a new idea about the effect of TAG structure on the activity of $\gamma$-oryzanol as a natural antioxidant was introduced. The proven hypothesis, signifying the inhibitory effect of TAG structure on the $\gamma$-oryzanol activity, can be useful in reinforcing a theory. Accordingly, although the esterification of fatty acids by the plant's metabolic system in the TAG structure reduces the access of oxidizing agents to oxidative sites; however, it shows undesirable effects on the access of available antioxidants in the medium to the oxidation active sites. Besides, a new approach for calculating the rate constant of LOOH formation was developed to provide accurate experience data about lipid oxidation.

\section{Acknowledgments}

This work was financially supported by Shiraz University.

\section{Conflict of Interest}

The authors declare no conflict of interest.

\section{References}


AOCS. (2009) Official methods and recommended practices of the AOCS: Sampling and analysis of commercial fats and oils, 6th ed., D. Firestone, (Ed.). AOCS Press, Champaign, IL, Ce 2-66.

Atkins, P. W., \& De Paula, J. (2006) Atkins' physical chemistry. 8th Edition, Oxford University Press , Oxford, New York.

Dijkstra, A. J. (2017) Kinetics without mechanism. European Journal of Lipid Science and Technology, 119: 1700001. https://doi.org/10.1002/ejlt.201700001

Fatemi, S. H., \& Hammond, E. G. (1980) Analysis of oleate, linoleate and linolenate hydroperoxides in oxidized ester mixtures. Lipids ,15: 379-385. https://doi.org/10.1007/BF02533555

Farhoosh, R. (2018) A kinetic approach to evaluate the structure-based performance of antioxidants during lipid oxidation. Journal of Food Science, 83 : 101-107. https://doi.org/10.1111/1750-3841.13993

Farhoosh, R., \& Hoseini-Yazdi, S. Z. (2014) Evolution of oxidative values during kinetic studies on olive oil oxidation in the Rancimat test. Journal of the American Oil Chemists' Society, 91 : 281-293. https://doi.org/10.1007/s11746-013-2368-z

Farhoosh, R., Niazmand, R., Rezaei, M., \& Sarabi, M. (2008) Kinetic parameter determination of vegetable oil oxidation under Rancimat test conditions. European Journal of Lipid Science and Technology, 110 : 587-592. https://doi.org/10.1002/ejlt.200800004

Frankel, E. N. (1998) Lipid Oxidation. The Oily Press, Dundee, Scotland, 1-303.

Golmakani, M-T., Keramat, M., \& Zare Darniyani, L. (2020) A kinetic approach to the oxidation of linseed oil as influenced by fruit peel and seeds of pomegranate. European Journal of Lipid Science and Technology , 122 : 1900084. https://doi.org/10.1002/ejlt.201900084

Hsieh, R. J., \& Kinsella, J. E. (1989) Oxidation of polyunsaturated fatty acids: mechanisms, products, and inhibition with emphasis on fish.Advances in Food and Nutrition Research , 33 : 233-341. https://doi.org/10.1016/S1043-4526(08)60129-1

Kahl, R., \& Hildebrandt, A. G. (1986) Methodology for studying antioxidant activity and mechanisms of action of antioxidant. Food and Chemical Toxicology , 24 : 1007-1014. https://doi.org/10.1016/02786915(86)90281-4

Marinova, E. M., \& Yanishlieva, N. V. (1995) Antioxidative activity of phenolic acids on triacylglycerols and fatty acid methyl esters from olive oil. Food Chemistry, 56 : 139-145. https://doi.org/10.1016/03088146(95)00147-6

Marinova, E. M., \& Yanishlieva, N. V. (2009) Comparison of the antioxidative properties of caffeic and chlorogenic acids. Food Chemistry, 114 : 1498-1502. https://doi.org/10.1016/j.foodchem.2008.11.045

Sanders, T. A. B. (1989) Nutritional aspects of rancidity. In: Rancidity in Foods. Eds. J.C. Allen, R.J. Hamilton. El., London, pp. 125-139.

Shahidi, F. (2005) Bailey's Industrial oil and fat products. $6^{\text {th }}$ edition, Volume 1, Edible Oil and Fat Products: Chemistry, Properties, and Health Effects, John wiley and Sons, Hoboken, USA.

Shantha, N. C., \& Decker, E. A. (1994) Rapid, sensitive, iron-based spectrophotometric methods for determination of peroxide values of food lipids. Journal of AOAC International , 77 : 421-424. https://doi.org/10.1093/jaoac/77.2.421

Shim, S. D., \& Lee, S. J. (2011) Shelf-life prediction of perilla oil by considering the induction period of lipid oxidation. European Journal of Lipid Science and Technology , 113 : 904-909. https://doi.org/10.1002/ejlt.201000325 
Toorani, M. R., Farhoosh, R., Golmakani, M, \& Sharif, A. (2019) Antioxidant activity and mechanism of action of sesamol in triacylglycerols and fatty acid methyl esters of sesame, olive, and canola oils. LWT Food Science and Technology, 103 : 271-278. https://doi.org/10.1016/j.lwt.2019.01.012

Toorani, M. R., Golmakani, M., \& Hashemi-Gahruie, H. (2020) Antioxidant activity and inhibitory mechanism of $\gamma$-oryzanol as influenced by unsaturation degree of lipid systems. LWT - Food Science and Technology , in press. https://doi.org/10.1016/j.lwt.2020.109930

Veloso, A. C. A., Rodrigues, N., Ouarouer, Y., Zaghdoudi, K., Pereira, J. A., \& Peres, A. M. (2020) A kinetic-thermodynamic study of the effect of the cultivar/total phenols on the oxidative stability of olive oils. Journal of the American Oil Chemists' Society, 97 : 625-636. https://doi.org/10.1002/aocs.12351

Xu, Z., \& Godber, J. S. (1999) Purification and identification of components of $\gamma$-oryzanol in rice bran oil. Journal of Agriculture and Food Chemistry, 47 : 2724-2728. https://doi.org/10.1021/jf981175j

Table 1. Fatty acids composition (\%) of different vegetable oils.

\begin{tabular}{llllll}
\hline Fatty acid & Vegetable oil & Vegetable oil & Vegetable oil & Vegetable oil & Vegetable oil \\
\hline & Soybean & Sunflower & Corn & Sesame & Olive \\
C12:0 & - & - & - & - & $0.43 \pm 0.07^{\mathrm{a}}$ \\
C14:0 & $0.82 \pm 0.02^{\mathrm{a} *}$ & $0.20 \pm 0.01^{\mathrm{d}}$ & $0.62 \pm 0.07^{\mathrm{b}}$ & $0.29 \pm 0.04^{\mathrm{d}}$ & $0.44 \pm 0.05^{\mathrm{c}}$ \\
$\mathrm{C} 16: 0$ & $6.88 \pm 0.04^{\mathrm{d}}$ & $7.10 \pm 0.07^{\mathrm{d}}$ & $13.2 \pm 0.1^{\mathrm{c}}$ & $17.2 \pm 0.2^{\mathrm{a}}$ & $14.9 \pm 0.1^{\mathrm{b}}$ \\
$\mathrm{C} 16: 1$ & $0.27 \pm 0.02^{\mathrm{c}}$ & $0.10 \pm 0.01^{\mathrm{d}}$ & $0.41 \pm 0.05^{\mathrm{b}}$ & $0.12 \pm 0.02^{\mathrm{d}}$ & $1.66 \pm 0.11^{\mathrm{a}}$ \\
$\mathrm{C} 18: 0$ & $0.78 \pm 0.06^{\mathrm{c}}$ & $3.24 \pm 0.04^{\mathrm{a}}$ & $0.75 \pm 0.06^{\mathrm{c}}$ & $2.34 \pm 0.06^{\mathrm{b}}$ & $2.31 \pm 0.03^{\mathrm{b}}$ \\
$\mathrm{C} 18: 1$ & $24.8 \pm 0.1^{\mathrm{e}}$ & $28.3 \pm 0.08^{\mathrm{d}}$ & $30.1 \pm 0.2^{\mathrm{c}}$ & $31.0 \pm 0.2^{\mathrm{b}}$ & $62.5 \pm 0.3^{\mathrm{a}}$ \\
$\mathrm{C} 18: 2$ & $57.7 \pm 0.1^{\mathrm{b}}$ & $59.8 \pm 0.1^{\mathrm{a}}$ & $53.8 \pm 0.2^{\mathrm{c}}$ & $47.2 \pm 0.2^{\mathrm{d}}$ & $15.4 \pm 0.2^{\mathrm{e}}$ \\
$\mathrm{C} 18: 3$ & $7.45 \pm 0.06^{\mathrm{a}}$ & $0.42 \pm 0.03^{\mathrm{d}}$ & $0.64 \pm 0.04^{\mathrm{c}}$ & $1.18 \pm 0.1^{\mathrm{b}}$ & $1.24 \pm 0.05^{\mathrm{b}}$ \\
$\mathrm{C} 20: 0$ & $0.76 \pm 0.01^{\mathrm{a}}$ & $0.28 \pm 0.03^{\mathrm{c}}$ & $0.20 \pm 0.02^{\mathrm{c}}$ & $0.42 \pm 0.05^{\mathrm{b}}$ & $0.52 \pm 0.10^{\mathrm{b}}$ \\
$\mathrm{C} 22: 0$ & $0.27 \pm 0.01^{\mathrm{b}}$ & $0.63 \pm 0.02^{\mathrm{a}}$ & $0.14 \pm 0.02^{\mathrm{c}}$ & $0.24 \pm 0.02^{\mathrm{b}}$ & $0.26 \pm 0.03^{\mathrm{b}}$ \\
C22:1 & $0.24 \pm 0.01^{\mathrm{a}}$ & - & $0.09 \pm 0.01^{\mathrm{b}}$ & - & $0.11 \pm 0.03^{\mathrm{b}}$ \\
C24:0 & - & - & - & - & $0.20 \pm 0.04^{\mathrm{a}}$ \\
SFA ** & $9.51 \pm 0.06^{\mathrm{e}}$ & $11.4 \pm 0.1^{\mathrm{d}}$ & $14.9 \pm 0.3^{\mathrm{c}}$ & $20.5 \pm 0.1^{\mathrm{a}}$ & $19.1 \pm 0.1^{\mathrm{b}}$ \\
MUFA & $25.3 \pm 0.1^{\mathrm{d}}$ & $28.4 \pm 0.1^{\mathrm{c}}$ & $30.6 \pm 0.1^{\mathrm{b}}$ & $31.1 \pm 0.2^{\mathrm{b}}$ & $64.2 \pm 0.2^{\mathrm{a}}$ \\
PUFA & $65.2 \pm 0.2^{\mathrm{a}}$ & $60.2 \pm 0.1^{\mathrm{b}}$ & $54.4 \pm 0.2^{\mathrm{c}}$ & $48.4 \pm 0.3^{\mathrm{d}}$ & $16.7 \pm 0.2^{\mathrm{e}}$ \\
Cox & $7.79 \pm 0.02^{\mathrm{a}}$ & $6.53 \pm 0.01^{\mathrm{b}}$ & $5.98 \pm 0.01^{\mathrm{c}}$ & $5.43 \pm 0.04^{\mathrm{d}}$ & $2.48 \pm 0.02^{\mathrm{e}}$ \\
\hline
\end{tabular}

* In each row, averages ( \pm standard deviation) with different lowercase letters are statistically different $(P$ $<0.05)$

** Saturated fatty acids, Monounsaturated fatty acids, Polyunsaturated fatty acids, Calculated oxidizability $\mathrm{x}$ value.

Table 2. Thermal kinetic parameters of various lipid systems in the presence of $\gamma$-oryzanol. 


\begin{tabular}{|c|c|c|c|c|c|c|c|c|c|}
\hline $\begin{array}{l}\text { Lipid } \\
\text { systems }\end{array}$ & $\begin{array}{l}\text { Reaction } \\
\text { rate } \\
\text { con- } \\
\text { stant, } k \\
\times 10^{-7} \\
(\mathrm{~mol} \\
\left.\mathrm{L}^{-1} \mathrm{~s}^{-1}\right)\end{array}$ & $\begin{array}{l}\text { Reaction } \\
\text { rate } \\
\text { con- } \\
\text { stant, } k \\
\times 10^{-7} \\
(\mathrm{~mol} \\
\left.\mathrm{L}^{-1} \mathrm{~s}^{-1}\right)\end{array}$ & $\begin{array}{l}\text { Reaction } \\
\text { rate } \\
\text { con- } \\
\text { stant, } k \\
\times 10^{-7} \\
(\mathrm{~mol} \\
\left.\mathrm{L}^{-1} \mathrm{~s}^{-1}\right)\end{array}$ & $\begin{array}{l}\text { Reaction } \\
\text { rate } \\
\text { con- } \\
\text { stant, } k \\
\times 10^{-7} \\
(\mathrm{~mol} \\
\left.\mathrm{L}^{-1} \mathrm{~s}^{-1}\right)\end{array}$ & $\begin{array}{l}\text { Reaction } \\
\text { rate } \\
\text { con- } \\
\text { stant, } k \\
\times 10^{-7} \\
(\mathrm{~mol} \\
\left.\mathrm{L}^{-1} \mathrm{~s}^{-1}\right)\end{array}$ & & & $\begin{array}{l}\text { Arrhenius } \\
\text { equa- } \\
\text { tion } \\
\text { parameters }\end{array}$ & $\begin{array}{l}\text { Arrhenius } \\
\text { equa- } \\
\text { tion } \\
\text { parameters }\end{array}$ \\
\hline & $333 \mathrm{~K}$ & $343 \mathrm{~K}$ & $343 \mathrm{~K}$ & $353 \mathrm{~K}$ & $353 \mathrm{~K}$ & $\begin{array}{l}E_{\mathrm{a}}(\mathrm{kJ} \\
\left.\mathrm{mol}^{-1}\right)\end{array}$ & $\begin{array}{l}E_{\mathrm{a}}(\mathrm{kJ} \\
\left.\mathrm{mol}^{-1}\right)\end{array}$ & $\begin{array}{l}E_{\mathrm{a}}(\mathrm{kJ} \\
\left.\mathrm{mol}^{-1}\right)\end{array}$ & $\begin{array}{l}E_{\mathrm{a}}(\mathrm{kJ} \\
\left.\mathrm{mol}^{-1}\right)\end{array}$ \\
\hline \multicolumn{10}{|l|}{$\begin{array}{l}\text { Olive } \\
\text { oil }\end{array}$} \\
\hline $\begin{array}{l}\mathrm{TAG}_{\mathrm{Con}} \\
+\end{array}$ & $\begin{array}{l}4.43 \pm \\
0.02^{\mathrm{j} *}\end{array}$ & $\begin{array}{l}4.43 \pm \\
0.02^{\mathrm{j} *}\end{array}$ & $\begin{array}{l}9.49 \pm \\
0.24^{\mathrm{j}}\end{array}$ & $\begin{array}{l}9.49 \pm \\
0.24^{\mathrm{j}}\end{array}$ & $\begin{array}{l}19.32 \pm \\
0.10^{j}\end{array}$ & $\begin{array}{l}19.32 \pm \\
0.10^{\mathrm{j}}\end{array}$ & $\begin{array}{l}71.95 \pm \\
0.01^{\mathrm{g}}\end{array}$ & $\begin{array}{l}71.95 \pm \\
0.01^{\mathrm{g}}\end{array}$ & $\begin{array}{l}4.93 \pm \\
0.00^{\mathrm{i}}\end{array}$ \\
\hline $\mathrm{FAME}_{\mathrm{Con}}$ & $\begin{array}{l}5.25 \pm \\
0.04^{\mathrm{i}}\end{array}$ & $\begin{array}{l}5.25 \pm \\
0.04^{\mathrm{i}}\end{array}$ & $\begin{array}{l}11.01 \pm \\
0.16^{\mathrm{i}}\end{array}$ & $\begin{array}{l}11.01 \pm \\
0.16^{\mathrm{i}}\end{array}$ & $\begin{array}{l}22.44 \pm \\
0.1^{\mathrm{i}}\end{array}$ & $\begin{array}{l}22.44 \pm \\
0.1^{\mathrm{i}}\end{array}$ & $\begin{array}{l}70.94 \pm \\
0.15^{\mathrm{h}}\end{array}$ & $\begin{array}{l}70.94 \pm \\
0.15^{\mathrm{h}}\end{array}$ & $\begin{array}{l}4.85 \pm \\
0.02^{\mathrm{j}}\end{array}$ \\
\hline $\begin{array}{l}\text { TAG } \\
++\end{array}$ & $\begin{array}{l}0.73 \pm \\
0.01^{\mathrm{r}}\end{array}$ & $\begin{array}{l}0.73 \pm \\
0.01^{\mathrm{r}}\end{array}$ & $\begin{array}{l}1.84 \pm \\
0.02^{\mathrm{r}}\end{array}$ & $\begin{array}{l}1.84 \pm \\
0.02^{\mathrm{r}}\end{array}$ & $\begin{array}{l}4.32 \pm \\
0.06^{\mathrm{s}}\end{array}$ & $\begin{array}{l}4.32 \pm \\
0.06^{\mathrm{s}}\end{array}$ & $\begin{array}{l}86.77 \pm \\
0.17^{\mathrm{b}}\end{array}$ & $\begin{array}{l}86.77 \pm \\
0.17^{\mathrm{b}}\end{array}$ & $\begin{array}{l}6.48 \pm \\
0.03^{\mathrm{ef}}\end{array}$ \\
\hline $\mathrm{FAME}_{\text {Ory }}$ & $\begin{array}{l}0.63 \pm \\
0.01^{\mathrm{s}}\end{array}$ & $\begin{array}{l}0.63 \pm \\
0.01^{\mathrm{s}}\end{array}$ & $\begin{array}{l}1.55 \pm \\
0.02^{\mathrm{s}}\end{array}$ & $\begin{array}{l}1.55 \pm \\
0.02^{\mathrm{s}}\end{array}$ & $\begin{array}{l}3.85 \pm \\
0.06^{\mathrm{t}}\end{array}$ & $\begin{array}{l}3.85 \pm \\
0.06^{\mathrm{t}}\end{array}$ & $\begin{array}{l}88.04 \pm \\
0.31^{\mathrm{a}}\end{array}$ & $\begin{array}{l}88.04 \pm \\
0.31^{\mathrm{a}}\end{array}$ & $\begin{array}{l}6.61 \pm \\
0.05^{\mathrm{cd}}\end{array}$ \\
\hline \multicolumn{10}{|l|}{$\begin{array}{l}\text { Sesame } \\
\text { oil }\end{array}$} \\
\hline $\mathrm{TAG}_{\mathrm{Con}}$ & $\begin{array}{l}9.22 \pm \\
0.20^{\mathrm{h}}\end{array}$ & $\begin{array}{l}9.22 \pm \\
0.20^{\mathrm{h}}\end{array}$ & $\begin{array}{l}18.74 \pm \\
0.47^{\mathrm{h}}\end{array}$ & $\begin{array}{l}18.74 \pm \\
0.47^{\mathrm{h}}\end{array}$ & $\begin{array}{l}36.22 \pm \\
0.68^{\mathrm{h}}\end{array}$ & $\begin{array}{l}36.22 \pm \\
0.68^{\mathrm{h}}\end{array}$ & $\begin{array}{l}66.85 \pm \\
0.18^{\mathrm{i}}\end{array}$ & $\begin{array}{l}66.85 \pm \\
0.18^{\mathrm{i}}\end{array}$ & $\begin{array}{l}4.45 \pm \\
0.02^{\mathrm{k}}\end{array}$ \\
\hline FAME $_{\text {Con }}$ & $\begin{array}{l}10.62 \pm \\
0.39^{g}\end{array}$ & $\begin{array}{l}10.62 \pm \\
0.39^{g}\end{array}$ & $\begin{array}{l}20.48 \pm \\
0.71^{\mathrm{g}}\end{array}$ & $\begin{array}{l}20.48 \pm \\
0.71^{\mathrm{g}}\end{array}$ & $\begin{array}{l}41.03 \pm \\
1.45^{\mathrm{g}}\end{array}$ & $\begin{array}{l}41.03 \pm \\
1.45^{\mathrm{g}}\end{array}$ & $\begin{array}{l}66.03 \pm \\
0.19^{\mathrm{j}}\end{array}$ & $\begin{array}{l}66.03 \pm \\
0.19^{j}\end{array}$ & $\begin{array}{l}4.38 \pm \\
0.03^{\mathrm{k}}\end{array}$ \\
\hline TAG ${ }_{\text {Ory }}$ & $\begin{array}{l}1.81 \pm \\
0.01^{\mathrm{n}}\end{array}$ & $\begin{array}{l}1.81 \pm \\
0.01^{\mathrm{n}}\end{array}$ & $\begin{array}{l}4.37 \pm \\
0.04^{\mathrm{o}}\end{array}$ & $\begin{array}{l}4.37 \pm \\
0.04^{\mathrm{o}}\end{array}$ & $\begin{array}{l}10.08 \pm \\
0.11^{\mathrm{o}}\end{array}$ & $\begin{array}{l}10.08 \pm \\
0.11^{\mathrm{o}}\end{array}$ & $\begin{array}{l}83.93 \pm \\
0.19^{\mathrm{b}}\end{array}$ & $\begin{array}{l}83.93 \pm \\
0.19^{\mathrm{b}}\end{array}$ & $\begin{array}{l}6.42 \pm \\
0.03^{\mathrm{f}}\end{array}$ \\
\hline FAME $_{\text {Ory }}$ & $\begin{array}{l}1.67 \pm \\
0.02^{\mathrm{p}}\end{array}$ & $\begin{array}{l}1.67 \pm \\
0.02^{\mathrm{p}}\end{array}$ & $\begin{array}{l}3.65 \pm \\
0.05^{\mathrm{q}}\end{array}$ & $\begin{array}{l}3.65 \pm \\
0.05^{\mathrm{q}}\end{array}$ & $\begin{array}{l}9.54 \pm \\
0.10^{\mathrm{q}}\end{array}$ & $\begin{array}{l}9.54 \pm \\
0.10^{\mathrm{q}}\end{array}$ & $\begin{array}{l}84.98 \pm \\
0.11^{\mathrm{d}}\end{array}$ & $\begin{array}{l}84.98 \pm \\
0.11^{\mathrm{d}}\end{array}$ & $\begin{array}{l}6.54 \pm \\
0.02^{\mathrm{de}}\end{array}$ \\
\hline \multicolumn{10}{|l|}{$\begin{array}{l}\text { Corn } \\
\text { oil }\end{array}$} \\
\hline $\mathrm{TAG}_{\mathrm{Con}}$ & $\begin{array}{l}11.19 \pm \\
0.11^{\mathrm{f}}\end{array}$ & $\begin{array}{l}11.19 \pm \\
0.11^{\mathrm{f}}\end{array}$ & $\begin{array}{l}23.81 \pm \\
0.26^{\mathrm{f}}\end{array}$ & $\begin{array}{l}23.81 \pm \\
0.26^{\mathrm{f}}\end{array}$ & $\begin{array}{l}42.09 \pm \\
0.53^{\mathrm{f}}\end{array}$ & $\begin{array}{l}42.09 \pm \\
0.53^{\mathrm{f}}\end{array}$ & $\begin{array}{l}64.80 \pm \\
0.14^{\mathrm{k}}\end{array}$ & $\begin{array}{l}64.80 \pm \\
0.14^{\mathrm{k}}\end{array}$ & $\begin{array}{l}4.22 \pm \\
0.03^{\mathrm{l}}\end{array}$ \\
\hline $\mathrm{FAME}_{\mathrm{Con}}$ & $\begin{array}{l}12.40 \pm \\
0.13^{\mathrm{e}}\end{array}$ & $\begin{array}{l}12.40 \pm \\
0.13^{\mathrm{e}}\end{array}$ & $\begin{array}{l}27.11 \pm \\
0.60^{\mathrm{e}}\end{array}$ & $\begin{array}{l}27.11 \pm \\
0.60^{\mathrm{e}}\end{array}$ & $\begin{array}{l}45.83 \pm \\
0.41^{\mathrm{e}}\end{array}$ & $\begin{array}{l}45.83 \pm \\
0.41^{\mathrm{e}}\end{array}$ & $\begin{array}{l}63.99 \pm \\
0.09^{\mathrm{l}}\end{array}$ & $\begin{array}{l}63.99 \pm \\
0.09^{1}\end{array}$ & $\begin{array}{l}4.15 \pm \\
0.01^{\mathrm{m}}\end{array}$ \\
\hline TAG Ory & $\begin{array}{l}1.74 \pm \\
0.00^{\circ}\end{array}$ & $\begin{array}{l}1.74 \pm \\
0.00^{\circ}\end{array}$ & $\begin{array}{l}4.24 \pm \\
0.05^{\mathrm{p}}\end{array}$ & $\begin{array}{l}4.24 \pm \\
0.05^{\mathrm{p}}\end{array}$ & $\begin{array}{l}9.87 \pm \\
0.02^{\mathrm{p}}\end{array}$ & $\begin{array}{l}9.87 \pm \\
0.02^{\mathrm{p}}\end{array}$ & $\begin{array}{l}84.78 \pm \\
0.12^{\mathrm{d}}\end{array}$ & $\begin{array}{l}84.78 \pm \\
0.12^{\mathrm{d}}\end{array}$ & $\begin{array}{l}6.54 \pm \\
0.02^{\mathrm{d}}\end{array}$ \\
\hline $\mathrm{FAME}_{\text {Ory }}$ & $\begin{array}{l}1.55 \pm \\
0.01^{\mathrm{q}}\end{array}$ & $\begin{array}{l}1.55 \pm \\
0.01^{\mathrm{q}}\end{array}$ & $\begin{array}{l}3.76 \pm \\
0.04^{\mathrm{q}}\end{array}$ & $\begin{array}{l}3.76 \pm \\
0.04^{\mathrm{q}}\end{array}$ & $\begin{array}{l}8.96 \pm \\
0.07^{\mathrm{r}}\end{array}$ & $\begin{array}{l}8.96 \pm \\
0.07^{\mathrm{r}}\end{array}$ & $\begin{array}{l}85.87 \pm \\
0.15^{\mathrm{c}}\end{array}$ & $\begin{array}{l}85.87 \pm \\
0.15^{\mathrm{c}}\end{array}$ & $\begin{array}{l}6.66 \pm \\
0.02^{\mathrm{c}}\end{array}$ \\
\hline \multicolumn{10}{|l|}{$\begin{array}{l}\text { Sunflower } \\
\text { oil }\end{array}$} \\
\hline $\mathrm{TAG}_{\mathrm{Con}}$ & $\begin{array}{l}13.06 \pm \\
0.22^{\mathrm{d}}\end{array}$ & $\begin{array}{l}13.06 \pm \\
0.22^{\mathrm{d}}\end{array}$ & $\begin{array}{l}29.68 \pm \\
1.07^{\mathrm{d}}\end{array}$ & $\begin{array}{l}29.68 \pm \\
1.07^{\mathrm{d}}\end{array}$ & $\begin{array}{l}47.33 \pm \\
0.90^{\mathrm{d}}\end{array}$ & $\begin{array}{l}47.33 \pm \\
0.90^{\mathrm{d}}\end{array}$ & $\begin{array}{l}63.05 \pm \\
0.12^{\mathrm{m}}\end{array}$ & $\begin{array}{l}63.05 \pm \\
0.12^{\mathrm{m}}\end{array}$ & $\begin{array}{l}4.03 \pm \\
0.03^{\mathrm{n}}\end{array}$ \\
\hline $\mathrm{FAME}_{\mathrm{Con}}$ & $\begin{array}{l}14.82 \pm \\
0.41^{\mathrm{c}}\end{array}$ & $\begin{array}{l}14.82 \pm \\
0.41^{\mathrm{c}}\end{array}$ & $\begin{array}{l}32.09 \pm \\
1.02^{\mathrm{c}}\end{array}$ & $\begin{array}{l}32.09 \pm \\
1.02^{\mathrm{c}}\end{array}$ & $\begin{array}{l}52.92 \pm \\
1.56^{\mathrm{c}}\end{array}$ & $\begin{array}{l}52.92 \pm \\
1.56^{\mathrm{c}}\end{array}$ & $\begin{array}{l}62.30 \pm \\
0.08^{\mathrm{n}}\end{array}$ & $\begin{array}{l}62.30 \pm \\
0.08^{\mathrm{n}}\end{array}$ & $\begin{array}{l}3.96 \pm \\
0.03^{\text {no }}\end{array}$ \\
\hline TAG ${ }_{\text {Ory }}$ & $\begin{array}{l}2.03 \pm \\
0.02^{\mathrm{m}}\end{array}$ & $\begin{array}{l}2.03 \pm \\
0.02^{\mathrm{m}}\end{array}$ & $\begin{array}{l}5.64 \pm \\
0.09^{\mathrm{m}}\end{array}$ & $\begin{array}{l}5.64 \pm \\
0.09^{\mathrm{m}}\end{array}$ & $\begin{array}{l}11.72 \pm \\
0.12^{\mathrm{m}}\end{array}$ & $\begin{array}{l}11.72 \pm \\
0.12^{\mathrm{m}}\end{array}$ & $\begin{array}{l}85.69 \pm \\
0.12^{\mathrm{c}}\end{array}$ & $\begin{array}{l}85.69 \pm \\
0.12^{\mathrm{c}}\end{array}$ & $\begin{array}{l}6.77 \pm \\
0.02^{\mathrm{b}}\end{array}$ \\
\hline $\mathrm{FAME}_{\text {Ory }}$ & $\begin{array}{l}1.76 \pm \\
0.02^{\text {no }}\end{array}$ & $\begin{array}{l}1.76 \pm \\
0.02^{\text {no }}\end{array}$ & $\begin{array}{l}4.73 \pm \\
0.04^{\mathrm{n}}\end{array}$ & $\begin{array}{l}4.73 \pm \\
0.04^{\mathrm{n}}\end{array}$ & $\begin{array}{l}10.39 \pm \\
0.13^{\mathrm{n}}\end{array}$ & $\begin{array}{l}10.39 \pm \\
0.13^{\mathrm{n}}\end{array}$ & $\begin{array}{l}86.79 \pm \\
0.11^{\mathrm{b}}\end{array}$ & $\begin{array}{l}86.79 \pm \\
0.11^{\mathrm{b}}\end{array}$ & $\begin{array}{l}6.87 \pm \\
0.02^{\mathrm{a}}\end{array}$ \\
\hline
\end{tabular}




\begin{tabular}{|c|c|c|c|c|c|c|c|c|c|}
\hline $\begin{array}{l}\text { Lipid } \\
\text { systems }\end{array}$ & $\begin{array}{l}\text { Reaction } \\
\text { rate } \\
\text { con- } \\
\text { stant, } k \\
\times 10^{-7} \\
(\mathrm{~mol} \\
\left.\mathrm{L}^{-1} \mathrm{~s}^{-1}\right)\end{array}$ & $\begin{array}{l}\text { Reaction } \\
\text { rate } \\
\text { con- } \\
\text { stant, } k \\
\times 10^{-7} \\
(\mathrm{~mol} \\
\left.\mathrm{L}^{-1} \mathrm{~s}^{-1}\right)\end{array}$ & $\begin{array}{l}\text { Reaction } \\
\text { rate } \\
\text { con- } \\
\text { stant, } k \\
\times 10^{-7} \\
(\mathrm{~mol} \\
\left.\mathrm{L}^{-1} \mathrm{~s}^{-1}\right)\end{array}$ & $\begin{array}{l}\text { Reaction } \\
\text { rate } \\
\text { con- } \\
\text { stant, } k \\
\times 10^{-7} \\
(\mathrm{~mol} \\
\left.\mathrm{L}^{-1} \mathrm{~s}^{-1}\right)\end{array}$ & $\begin{array}{l}\text { Reaction } \\
\text { rate } \\
\text { con- } \\
\text { stant, } k \\
\times 10^{-7} \\
\left(\mathrm{~mol}^{-1}\right. \\
\left.\mathrm{L}^{-1} \mathrm{~s}^{-1}\right)\end{array}$ & & & $\begin{array}{l}\text { Arrhenius } \\
\text { equa- } \\
\text { tion } \\
\text { parameters }\end{array}$ & $\begin{array}{l}\text { Arrhenius } \\
\text { equa- } \\
\text { tion } \\
\text { parameters }\end{array}$ \\
\hline \multicolumn{10}{|l|}{$\begin{array}{l}\text { Soybean } \\
\text { oil }\end{array}$} \\
\hline $\mathrm{TAG}_{\mathrm{Con}}$ & $\begin{array}{l}17.45 \pm \\
0.32^{\mathrm{b}}\end{array}$ & $\begin{array}{l}17.45 \pm \\
0.32^{\mathrm{b}}\end{array}$ & $\begin{array}{l}36.80 \pm \\
1.25^{\mathrm{b}}\end{array}$ & $\begin{array}{l}36.80 \pm \\
1.25^{\mathrm{b}}\end{array}$ & $\begin{array}{l}61.73 \pm \\
1.25^{\mathrm{b}}\end{array}$ & $\begin{array}{l}61.73 \pm \\
1.25^{\mathrm{b}}\end{array}$ & $\begin{array}{l}61.83 \pm \\
0.12^{\circ}\end{array}$ & $\begin{array}{l}61.83 \pm \\
0.12^{\circ}\end{array}$ & $\begin{array}{l}3.95 \pm \\
0.03^{\text {no }}\end{array}$ \\
\hline FAME $_{\text {Con }}$ & $\begin{array}{l}19.43 \pm \\
0.41^{\mathrm{a}}\end{array}$ & $\begin{array}{l}19.43 \pm \\
0.41^{\mathrm{a}}\end{array}$ & $\begin{array}{l}43.26 \pm \\
1.37^{\mathrm{a}}\end{array}$ & $\begin{array}{l}43.26 \pm \\
1.37^{\mathrm{a}}\end{array}$ & $\begin{array}{l}67.89 \pm \\
1.35^{\mathrm{a}}\end{array}$ & $\begin{array}{l}67.89 \pm \\
1.35^{\mathrm{a}}\end{array}$ & $\begin{array}{l}61.27 \pm \\
0.10^{\mathrm{p}}\end{array}$ & $\begin{array}{l}61.27 \pm \\
0.10^{\mathrm{p}}\end{array}$ & $\begin{array}{l}3.92 \pm \\
0.01^{\circ}\end{array}$ \\
\hline TAG Ory & $\begin{array}{l}4.05 \pm \\
0.01^{\mathrm{k}}\end{array}$ & $\begin{array}{l}4.05 \pm \\
0.01^{\mathrm{k}}\end{array}$ & $\begin{array}{l}9.74 \pm \\
0.14^{\mathrm{k}}\end{array}$ & $\begin{array}{l}9.74 \pm \\
0.14^{\mathrm{k}}\end{array}$ & $\begin{array}{l}18.55 \pm \\
0.07^{\mathrm{k}}\end{array}$ & $\begin{array}{l}18.55 \pm \\
0.07^{\mathrm{k}}\end{array}$ & $\begin{array}{l}74.40 \pm \\
0.08^{\mathrm{f}}\end{array}$ & $\begin{array}{l}74.40 \pm \\
0.08^{\mathrm{f}}\end{array}$ & $\begin{array}{l}5.29 \pm \\
0.02^{\mathrm{h}}\end{array}$ \\
\hline FAME $_{\text {Ory }}$ & $\begin{array}{l}3.65 \pm \\
0.02^{1}\end{array}$ & $\begin{array}{l}3.65 \pm \\
0.02^{1}\end{array}$ & $\begin{array}{l}8.91 \pm \\
0.13^{1}\end{array}$ & $\begin{array}{l}8.91 \pm \\
0.13^{1}\end{array}$ & $\begin{array}{l}17.39 \pm \\
0.06^{1}\end{array}$ & $\begin{array}{l}17.39 \pm \\
0.06^{1}\end{array}$ & $\begin{array}{l}76.03 \pm \\
0.10^{\mathrm{e}}\end{array}$ & $\begin{array}{l}76.03 \pm \\
0.10^{\mathrm{e}}\end{array}$ & $\begin{array}{l}5.46 \pm \\
0.01^{\mathrm{g}}\end{array}$ \\
\hline
\end{tabular}

* Averages ( \pm standard deviation) within a column with the same lowercase letters are not statistically different $(p<0.05)$.

+ TAG and FAME systems in the non-inhibited peroxidation, ++ TAG and FAME systems in the presence of $\gamma$-oryzanol.

Table 3. Thermodynamic and kinetic parameters of various lipid systems in the absence and presence of $\gamma$-oryzanol.

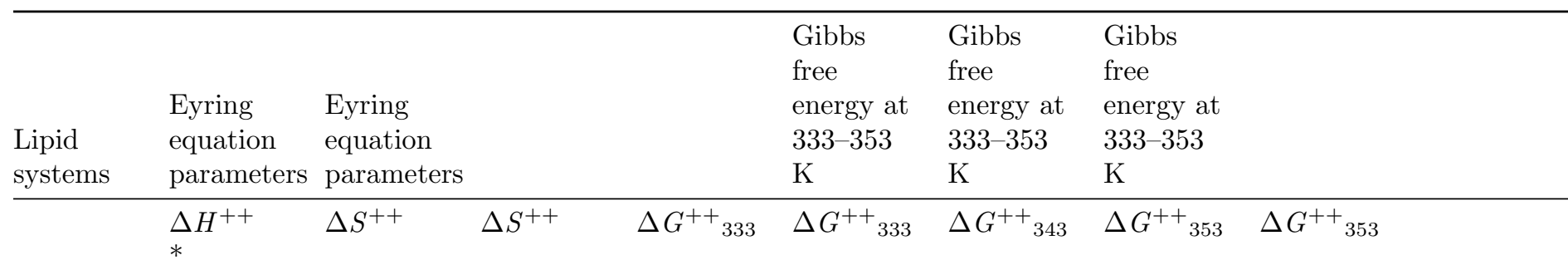

Olive

oil

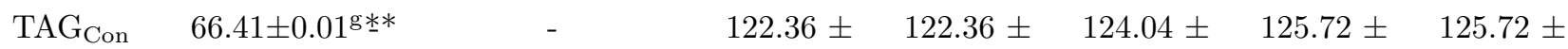
$+\quad 168.02 \pm 0.07^{\mathrm{i}} 168.02 \pm 0.07^{\mathrm{i}} 0.01^{\mathrm{k}} \quad 0.01^{\mathrm{k}} \quad 0.02^{\mathrm{k}} \quad 0.02^{\mathrm{k}} \quad 0.02^{\mathrm{k}}$

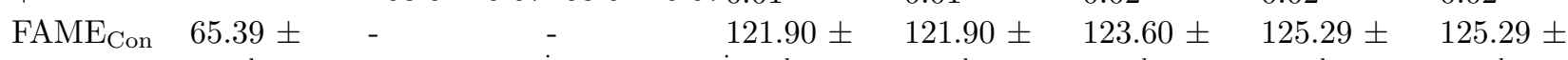

\begin{tabular}{|c|c|c|c|c|c|c|c|}
\hline & $0.15^{\mathrm{h}}$ & $169.69 \pm 0.38^{j} 169.69 \pm 0.380^{0} .03^{1}$ & $0.03^{\mathrm{l}}$ & $0.02^{1}$ & $0.02^{1}$ & $0.02^{1}$ & \\
\hline AG & $\begin{array}{l}81.22 \pm \\
0.17^{\mathrm{b}}\end{array}$ & $\begin{array}{ccc}- & - & 127.34 \pm \\
138.49 \pm 0.577^{\mathrm{g}} 38.49 \pm 0.57 ð .03^{\mathrm{b}}\end{array}$ & $\begin{array}{l}127.34 \pm \\
0.03^{\mathrm{b}}\end{array}$ & $\begin{array}{l}128.73 \pm \\
0.03^{\mathrm{b}}\end{array}$ & $\begin{array}{l}130.11 \pm \\
0.04^{\mathrm{b}}\end{array}$ & $\begin{array}{l}130.11 \pm \\
0.04^{\mathrm{b}}\end{array}$ & $\begin{array}{l}2.01 \pm \\
0.00^{\mathrm{a}}\end{array}$ \\
\hline & $\begin{array}{l}82.50 \pm \\
0.31^{\mathrm{a}}\end{array}$ & $\begin{array}{lc}- & 127.78 \pm \\
135.96 \pm 1.009955 .96 \pm 1.00 @ 1.02^{\mathrm{a}}\end{array}$ & $\begin{array}{l}127.78 \pm \\
0.02^{\mathrm{a}}\end{array}$ & $\begin{array}{l}129.14 \pm \\
0.03^{\mathrm{a}}\end{array}$ & $\begin{array}{l}130.50 \pm \\
0.04^{\mathrm{a}}\end{array}$ & $\begin{array}{l}130.50 \pm \\
0.04^{\mathrm{a}}\end{array}$ & \\
\hline
\end{tabular}

Sesame

oil

\begin{tabular}{|c|c|c|c|c|c|c|c|}
\hline $\mathrm{TAG}_{\text {Con }}$ & $\begin{array}{l}61.30 \pm \\
0.18^{\mathrm{i}}\end{array}$ & $\begin{array}{l}- \\
177.26 \pm 0.45\end{array}$ & $-\frac{120.33}{477.26 \pm 0.45^{\mathrm{k}}+0.06^{\mathrm{m}}}$ & $\begin{array}{l}120.33 \\
\pm 0.06^{\mathrm{m}}\end{array}$ & $\begin{array}{l}122.10 \\
\pm 0.06^{\mathrm{m}}\end{array}$ & $\begin{array}{l}123.88 \pm \\
0.06^{\mathrm{m}}\end{array}$ & $\begin{array}{l}123.88 \pm \\
0.06^{\mathrm{m}}\end{array}$ \\
\hline FAMF & $\begin{array}{l}60.48 \pm \\
0.19^{\mathrm{j}}\end{array}$ & $\begin{array}{l}- \\
178.67 \pm 0.57\end{array}$ & $\begin{array}{c}119.98 \pm \\
778.67 \pm 0.570 .10^{\mathrm{n}}\end{array}$ & $\begin{array}{l}119.98 \pm \\
0.10^{\mathrm{n}}\end{array}$ & $\begin{array}{l}121.77 \pm \\
0.10^{\mathrm{n}}\end{array}$ & $\begin{array}{l}123.55 \pm \\
0.10^{\mathrm{n}}\end{array}$ & $\begin{array}{l}123.55 \pm \\
0.10^{\mathrm{n}}\end{array}$ \\
\hline
\end{tabular}




\begin{tabular}{|c|c|c|c|c|c|c|c|}
\hline $\begin{array}{l}\text { Lipid } \\
\text { systems }\end{array}$ & $\begin{array}{l}\text { Eyring } \\
\text { equation } \\
\text { parameters }\end{array}$ & $\begin{array}{l}\text { Eyring } \\
\text { equation } \\
\text { parameters }\end{array}$ & $\begin{array}{l}\text { Gibbs } \\
\text { free } \\
\text { energy at } \\
333-353 \\
\text { K }\end{array}$ & $\begin{array}{l}\text { Gibbs } \\
\text { free } \\
\text { energy at } \\
333-353 \\
\mathrm{~K}\end{array}$ & $\begin{array}{l}\text { Gibbs } \\
\text { free } \\
\text { energy at } \\
333-353 \\
\mathrm{~K}\end{array}$ & & \\
\hline TAG Ory & $\begin{array}{l}78.39 \pm \\
0.19^{\mathrm{b}}\end{array}$ & $\begin{array}{lcc}- & - & 124.85 \\
139.52 \pm 0.61^{\mathrm{f}} 139.52 \pm 0.61^{00} 02^{\mathrm{g}}\end{array}$ & $\begin{array}{l}124.85 \pm \\
0.02^{\mathrm{g}}\end{array}$ & $\begin{array}{l}126.24 \pm \\
0.03^{\mathrm{g}}\end{array}$ & $\begin{array}{l}127.64 \pm \\
0.03^{\mathrm{g}}\end{array}$ & $\begin{array}{l}127.64 \pm \\
0.03^{\mathrm{g}}\end{array}$ & $\begin{array}{l}1.88 \pm \\
0.00^{\mathrm{b}}\end{array}$ \\
\hline FAME $_{\text {Ory }}$ & $\begin{array}{l}79.43 \pm \\
0.11^{\mathrm{d}}\end{array}$ & $\begin{array}{lcc}- & - & 125.17 \\
137.33 \pm 0.37937 .33 \pm 0.37 \mathcal{d e}^{\mathrm{de}} .03^{\mathrm{d}}\end{array}$ & $\begin{array}{l}125.17 \pm \\
0.03^{\mathrm{d}}\end{array}$ & $\begin{array}{l}126.54 \pm \\
0.03^{\mathrm{d}}\end{array}$ & $\begin{array}{l}127.91 \pm \\
0.03^{\mathrm{d}}\end{array}$ & $\begin{array}{l}127.91 \pm \\
0.03^{\mathrm{d}}\end{array}$ & $\begin{array}{l}1.88 \pm \\
0.01^{\mathrm{b}}\end{array}$ \\
\hline \multicolumn{8}{|l|}{$\begin{array}{l}\text { Corn } \\
\text { oil }\end{array}$} \\
\hline $\mathrm{TAG}_{\mathrm{Con}}$ & $\begin{array}{l}59.26 \pm \\
0.14^{\mathrm{k}}\end{array}$ & $\begin{array}{lc}- & 119.73 \\
181.60 \pm 0.49^{\mathrm{l}} 181.60 \pm 0.490 .02^{\circ}\end{array}$ & $\begin{array}{l}119.73 \pm \\
0.02^{\circ}\end{array}$ & $\begin{array}{l}121.55 \pm \\
0.03^{\circ}\end{array}$ & $\begin{array}{l}123.36 \pm \\
0.03^{\circ}\end{array}$ & $\begin{array}{l}123.36 \pm \\
0.03^{\circ}\end{array}$ & \\
\hline $\mathrm{FAME}_{\mathrm{Con}}$ & $\begin{array}{l}58.45 \pm \\
0.09^{1}\end{array}$ & $\begin{array}{ccc}- & - & 119.42 \\
183.10 \pm 0.23183 .10 \pm 0.23 \bigoplus .04^{\mathrm{p}}\end{array}$ & $\begin{array}{l}119.42 \pm \\
0.04^{\mathrm{p}}\end{array}$ & $\begin{array}{l}121.25 \pm \\
0.04^{\mathrm{p}}\end{array}$ & $\begin{array}{l}123.08 \pm \\
0.04^{\mathrm{p}}\end{array}$ & $\begin{array}{l}123.08 \pm \\
0.04^{\mathrm{p}}\end{array}$ & \\
\hline TAG Ory & $\begin{array}{l}79.24 \pm \\
0.12^{\mathrm{d}}\end{array}$ & $\begin{array}{lcc}- & - & 124.95 \pm \\
137.29 \pm 0.37937 .29 \pm 0.37 \oplus .01^{\mathrm{e}}\end{array}$ & $\begin{array}{l}124.95 \pm \\
0.01^{\mathrm{e}}\end{array}$ & $\begin{array}{l}126.32 \pm \\
0.01^{\mathrm{e}}\end{array}$ & $\begin{array}{l}127.70 \pm \\
0.01^{\mathrm{e}}\end{array}$ & $\begin{array}{l}127.70 \pm \\
0.01^{\mathrm{e}}\end{array}$ & $\begin{array}{l}1.85 \pm \\
0.00^{\mathrm{c}}\end{array}$ \\
\hline FAME $_{\text {Ory }}$ & $\begin{array}{l}80.33 \pm \\
0.15^{\mathrm{c}}\end{array}$ & $\begin{array}{cc}- & 125.29 \\
135.04 \pm 0.47935 .04 \pm 0.470 .02^{\mathrm{c}}\end{array}$ & $\begin{array}{l}125.29 \pm \\
0.02^{\mathrm{c}}\end{array}$ & $\begin{array}{l}126.64 \pm \\
0.02^{\mathrm{c}}\end{array}$ & $\begin{array}{l}127.99 \pm \\
0.03^{\mathrm{c}}\end{array}$ & $\begin{array}{l}127.99 \pm \\
0.03^{\mathrm{c}}\end{array}$ & $\begin{array}{l}1.84 \pm \\
0.00^{\mathrm{c}}\end{array}$ \\
\hline \multicolumn{8}{|l|}{$\begin{array}{l}\text { Sunflower } \\
\text { oil }\end{array}$} \\
\hline $\mathrm{TAG}_{\mathrm{Con}}$ & $\begin{array}{l}57.51 \pm \\
0.12^{\mathrm{m}}\end{array}$ & $\begin{array}{ccc}- & - & 119.23 \\
185.36 \pm 0.56185 .36 \pm 0.560 .06^{\mathrm{q}}\end{array}$ & $\begin{array}{l}119.23 \pm \\
0.06^{\mathrm{q}}\end{array}$ & $\begin{array}{l}121.08 \pm \\
0.07^{\mathrm{q}}\end{array}$ & $\begin{array}{l}122.94 \pm \\
0.07^{\mathrm{q}}\end{array}$ & $\begin{array}{l}122.94 \pm \\
0.07^{\mathrm{q}}\end{array}$ & \\
\hline FAME $_{\text {Con }}$ & $\begin{array}{l}56.76 \pm \\
0.08^{\mathrm{n}}\end{array}$ & $\begin{array}{ccc}- & 118.92 & \\
186.66 \pm 0.49186 .66 \pm 0.49 \bigoplus 9.08^{\mathrm{r}}\end{array}$ & $\begin{array}{l}118.92 \pm \\
0.08^{\mathrm{r}}\end{array}$ & $\begin{array}{l}120.78 \pm \\
0.08^{\mathrm{r}}\end{array}$ & $\begin{array}{l}122.65 \pm \\
0.09^{\mathrm{r}}\end{array}$ & $\begin{array}{l}122.65 \pm \\
0.09^{\mathrm{r}}\end{array}$ & \\
\hline $\mathrm{TAG}_{\text {Ory }}$ & $\begin{array}{l}80.14 \pm \\
0.12^{\mathrm{c}}\end{array}$ & $\begin{array}{lcc}- & - & 124.41 \pm \\
132.95 \pm 0.43132 .95 \pm 0.43 \emptyset .02^{\mathrm{h}}\end{array}$ & $\begin{array}{l}124.41 \pm \\
0.02^{\mathrm{h}}\end{array}$ & $\begin{array}{l}125.74 \pm \\
0.03^{\mathrm{h}}\end{array}$ & $\begin{array}{l}127.07 \pm \\
0.03^{\mathrm{h}}\end{array}$ & $\begin{array}{l}127.07 \pm \\
0.03^{\mathrm{h}}\end{array}$ & $\begin{array}{l}1.80 \pm \\
0.00^{\mathrm{d}}\end{array}$ \\
\hline FAME $_{\text {Ory }}$ & $\begin{array}{l}81.25 \pm \\
0.11^{\mathrm{b}}\end{array}$ & $\begin{array}{lcc}- & - & 124.85 \\
130.93 \pm 0.39130 .93 \pm 0.3900 .02^{\mathrm{f}}\end{array}$ & $\begin{array}{l}124.85 \pm \\
0.02^{\mathrm{f}}\end{array}$ & $\begin{array}{l}126.16 \pm \\
0.03^{\mathrm{f}}\end{array}$ & $\begin{array}{l}127.47 \pm \\
0.03^{\mathrm{f}}\end{array}$ & $\begin{array}{l}127.47 \pm \\
0.03^{f}\end{array}$ & $\begin{array}{l}1.80 \pm \\
0.00^{\mathrm{d}}\end{array}$ \\
\hline \multicolumn{8}{|l|}{$\begin{array}{l}\text { Soybean } \\
\text { oil }\end{array}$} \\
\hline $\mathrm{TAG}_{\mathrm{Con}}$ & $\begin{array}{l}56.29 \pm \\
0.12^{\mathrm{o}}\end{array}$ & $\begin{array}{ccc}- & - & 118.48 \\
186.78 \pm 0.52186 .78 \pm 0.52 ఱ 9.06^{\mathrm{s}}\end{array}$ & $\begin{array}{l}118.48 \pm \\
0.06^{\mathrm{s}}\end{array}$ & $\begin{array}{l}120.35 \pm \\
0.07^{\mathrm{s}}\end{array}$ & $\begin{array}{l}122.22 \pm \\
0.07^{\mathrm{s}}\end{array}$ & $\begin{array}{l}122.22 \pm \\
0.07^{\mathrm{s}}\end{array}$ & \\
\hline $\mathrm{FAME}_{\mathrm{Con}}$ & $\begin{array}{l}55.73 \pm \\
0.10^{\mathrm{p}}\end{array}$ & $\begin{array}{lcc}- & - & 118.13 \\
187.40 \pm 0.24987 .40 \pm 0.240 .07^{\mathrm{t}}\end{array}$ & $\begin{array}{l}118.13 \pm \\
0.07^{\mathrm{t}}\end{array}$ & $\begin{array}{l}120.00 \pm \\
0.07^{\mathrm{t}}\end{array}$ & $\begin{array}{l}121.88 \pm \\
0.07^{\mathrm{t}}\end{array}$ & $\begin{array}{l}121.88 \pm \\
0.07^{\mathrm{t}}\end{array}$ & \\
\hline TAG ${ }_{\text {Ory }}$ & $\begin{array}{l}68.85 \pm \\
0.08^{f}\end{array}$ & $\begin{array}{lcc}- & - & 122.53 \pm \\
161.18 \pm 0.29 & 161.18 \pm 0.290 .02^{\mathrm{j}}\end{array}$ & $\begin{array}{l}122.53 \pm \\
0.02^{\mathrm{j}}\end{array}$ & $\begin{array}{l}124.14 \pm \\
0.02^{\mathrm{j}}\end{array}$ & $\begin{array}{l}125.75 \pm \\
0.02^{\mathrm{j}}\end{array}$ & $\begin{array}{l}125.75 \pm \\
0.02^{\mathrm{j}}\end{array}$ & $\begin{array}{l}1.79 \pm \\
0.00^{\mathrm{d}}\end{array}$ \\
\hline FAME $_{\text {Ory }}$ & $\begin{array}{l}70.49 \pm \\
0.10^{\mathrm{e}}\end{array}$ & $\begin{array}{cc}- & 123.11 \pm \\
158.03 \pm 0.269 & 158.03 \pm 0.26 \varnothing .02^{\mathrm{i}}\end{array}$ & $\begin{array}{l}123.11 \pm \\
0.02^{\mathrm{i}}\end{array}$ & $\begin{array}{l}124.69 \pm \\
0.02^{\mathrm{i}}\end{array}$ & $\begin{array}{l}126.27 \pm \\
0.02^{\mathrm{i}}\end{array}$ & $\begin{array}{l}126.27 \pm \\
0.02^{\mathrm{i}}\end{array}$ & $\begin{array}{l}1.79 \pm \\
0.00^{\mathrm{d}}\end{array}$ \\
\hline
\end{tabular}

$* \Delta H^{++}$enthalpy of activation $(\mathrm{kJ} / \mathrm{mol}), \Delta S^{++}$entropy of activation $(\mathrm{J} / \mathrm{mol}), \Delta G{ }^{++}$Gibbs free energy $(\mathrm{kJ} / \mathrm{mol})$ at various temperature $(\mathrm{K}), \mathrm{Ef}_{\mathrm{d}}$ decrease in the effectiveness of $\gamma$-oryzanol by increasing temperature.

** Averages ( \pm standard deviation) within a column with the same lowercase letters are not statistically different $(p<0.05)$.

+ Triacylglycerol and fatty acids methyl esters systems in the non-inhibited peroxidation.

++ Triacylglycerol and fatty acids methyl esters systems in the presence of $\gamma$-oryzanol. 


\section{Figure captions:}

Fig. 1 Molecular structure of $\gamma$-oryzanol.

Fig. 2 Schematic kinetic curve of lipid hydroperoxides (LOOH) accumulation during oxidation. IP: Induction period, $\mathrm{LOOH}_{\mathrm{IP}}$ : the concentration of the produced LOOH in IP point, ISRG or PSRG: the initiation or propagation stage related to the graph, ELFISO or ELFPSO: the equation of line fitted on the initiation or propagation stage of oxidation, $\mathrm{a}_{\mathrm{I}}$ or $\mathrm{a}_{\mathrm{P}}$ and $\mathrm{b}_{\mathrm{I}}$ or $\mathrm{b}_{\mathrm{P}}$ : slope and intercept of ELFISO or ELFPSO, respectively.

Fig. 3 Correlations between the length of induction period (IP) and the produced hydroperoxides in this point $\left(\mathrm{LOOH}_{\mathrm{IP}}\right)$ for different lipid systems in presence of $\gamma$-oryzanol at 60,70 , and $80{ }^{\circ} \mathrm{C}$.

Fig. 4 Temperature dependence and the obtained equations of the stabilization factor of $\gamma$-oryzanol for different lipid systems.

Fig. 5 The difference caused by the presence of $\gamma$-oryzanol in Triacylglycerol (TAG) and Fatty acid methyl esters (FAME) systems for activation energy $\left(E_{\mathrm{a}}\right)$ and entropy of activation $\left(\Delta S^{++}\right)$in different vegetable oils.

Fig. 6 Percentage changes in the kinetic and thermodynamic parameters in different vegetable oils.

Fig. 7 Percentage changes in Gibbs free energy $\left(\Delta G^{++}\right)$in the presence of $\gamma$-oryzanol at different (a) temperatures (343-353 K) and (b) lipid systems.

Fig. 8 Correlation between the logarithm of induction period (IP) and values of Gibbs free energy ( $\Delta G$ ${ }^{++}$) for lipid systems at (a) $333 \mathrm{~K}$, (b) $343 \mathrm{~K}$, and (c) $353 \mathrm{~K}$.

Fig. 9 Changes in kinetic and thermodynamic parameters in the presence of $\gamma$-oryzanol for different lipid systems. $A$ : frequency factor, $\Delta H{ }^{++}$: activation Enthalpy, $E$ a: activation energy, $\Delta S{ }^{++}$: activation Entropy, $\Delta G^{++}$: Gibbs free energy at different temperatures, DBFT: the difference between FAME and TAG.

Fig. 10 Correlation between the reducing the effectiveness of $\gamma$-oryzanol $\left(\mathrm{Ef}_{\mathrm{d}}\right.$, due to a $10{ }^{\circ} \mathrm{C}$ increase in temperature) and calculated oxidative stability index (Cox) of different studied oils for Triacylglycerol (TAG) and Fatty acid methyl ester (FAME) systems. 


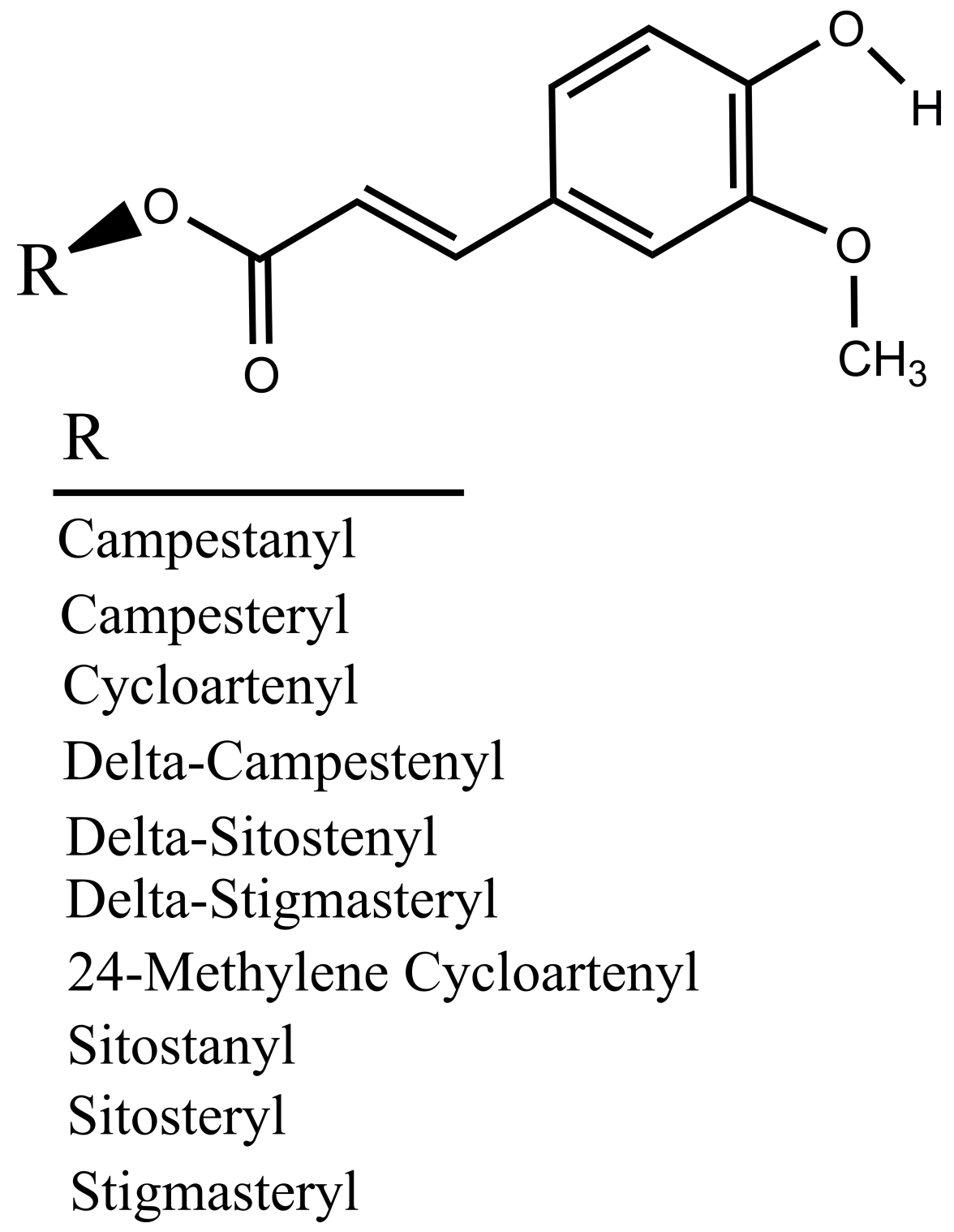



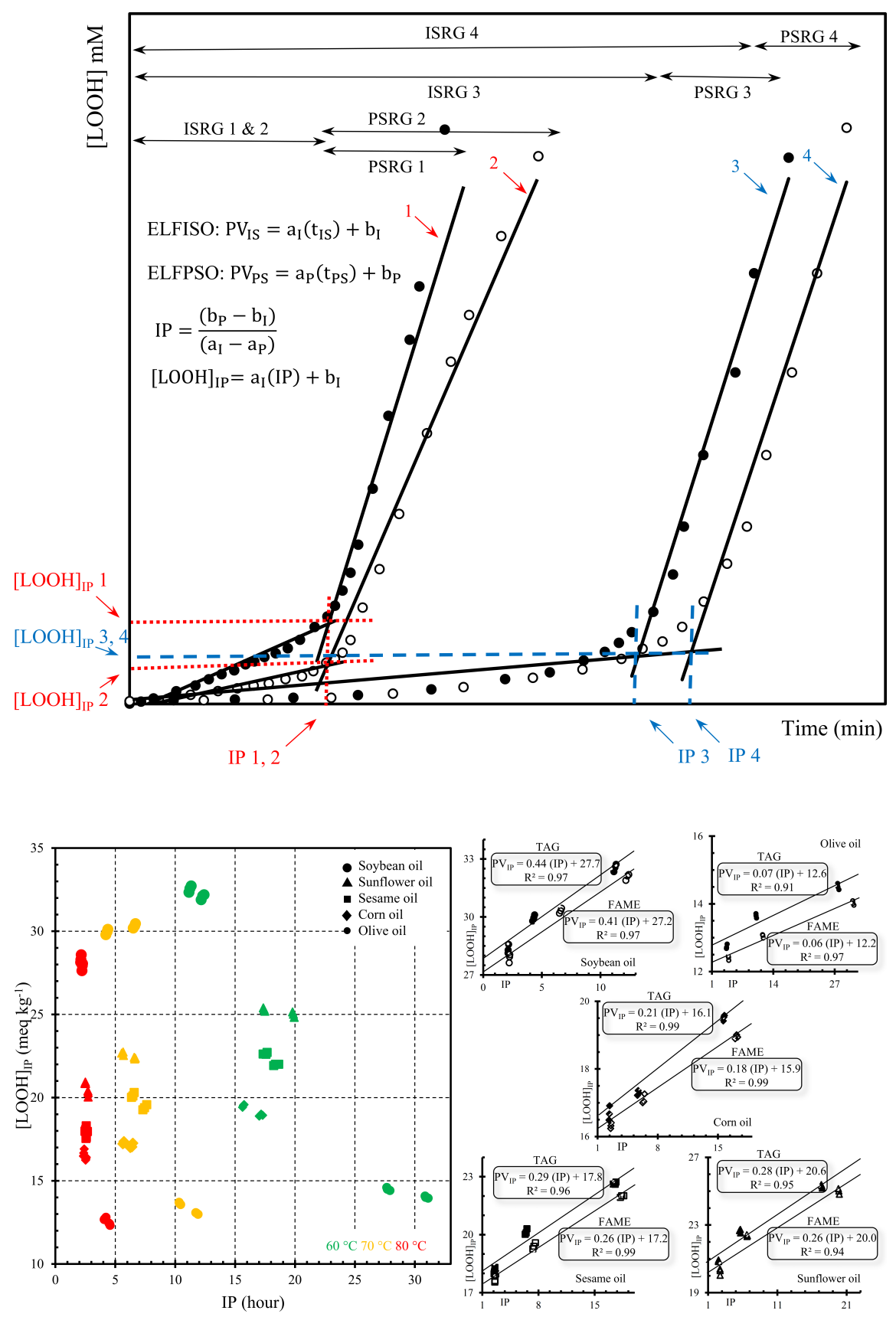

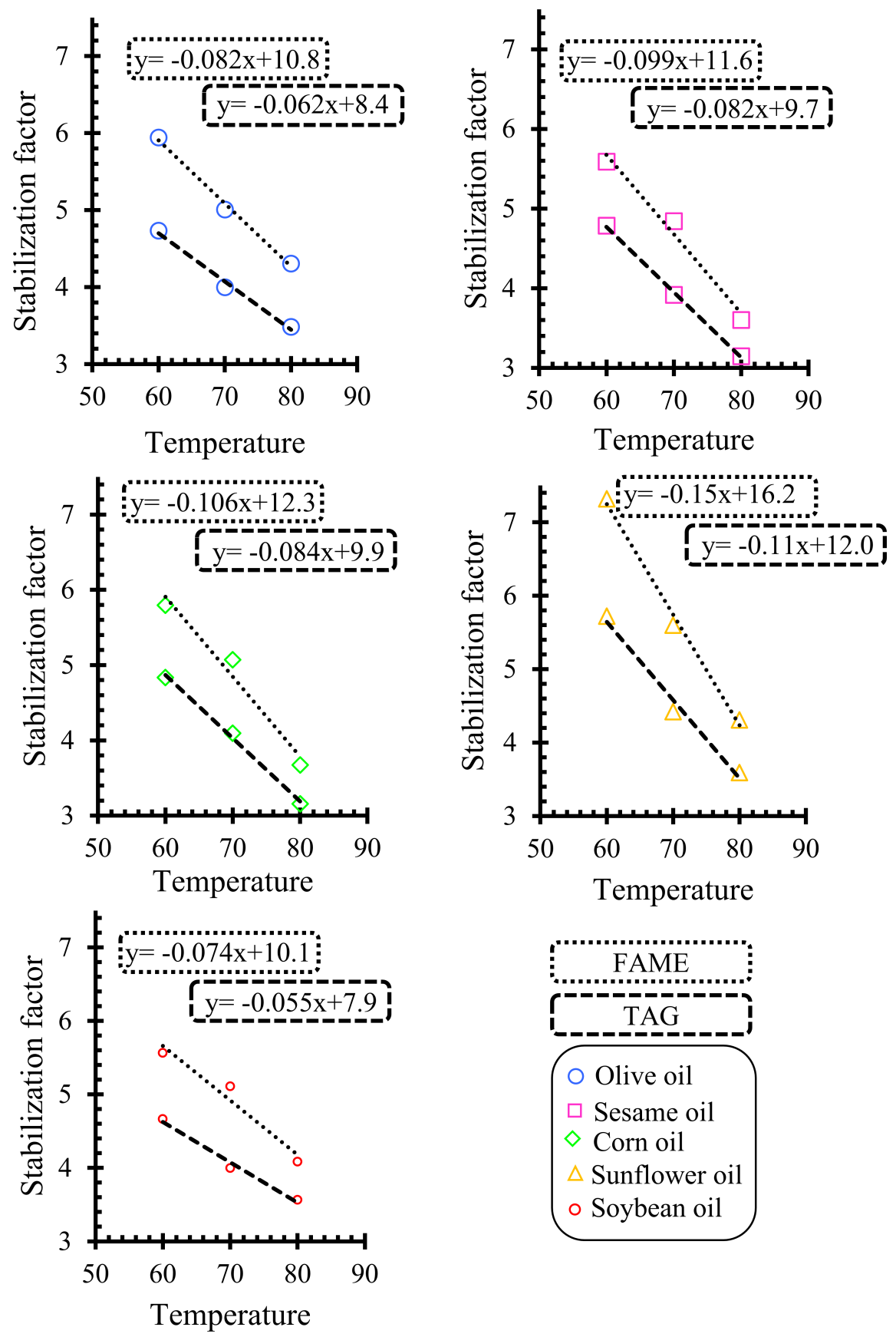


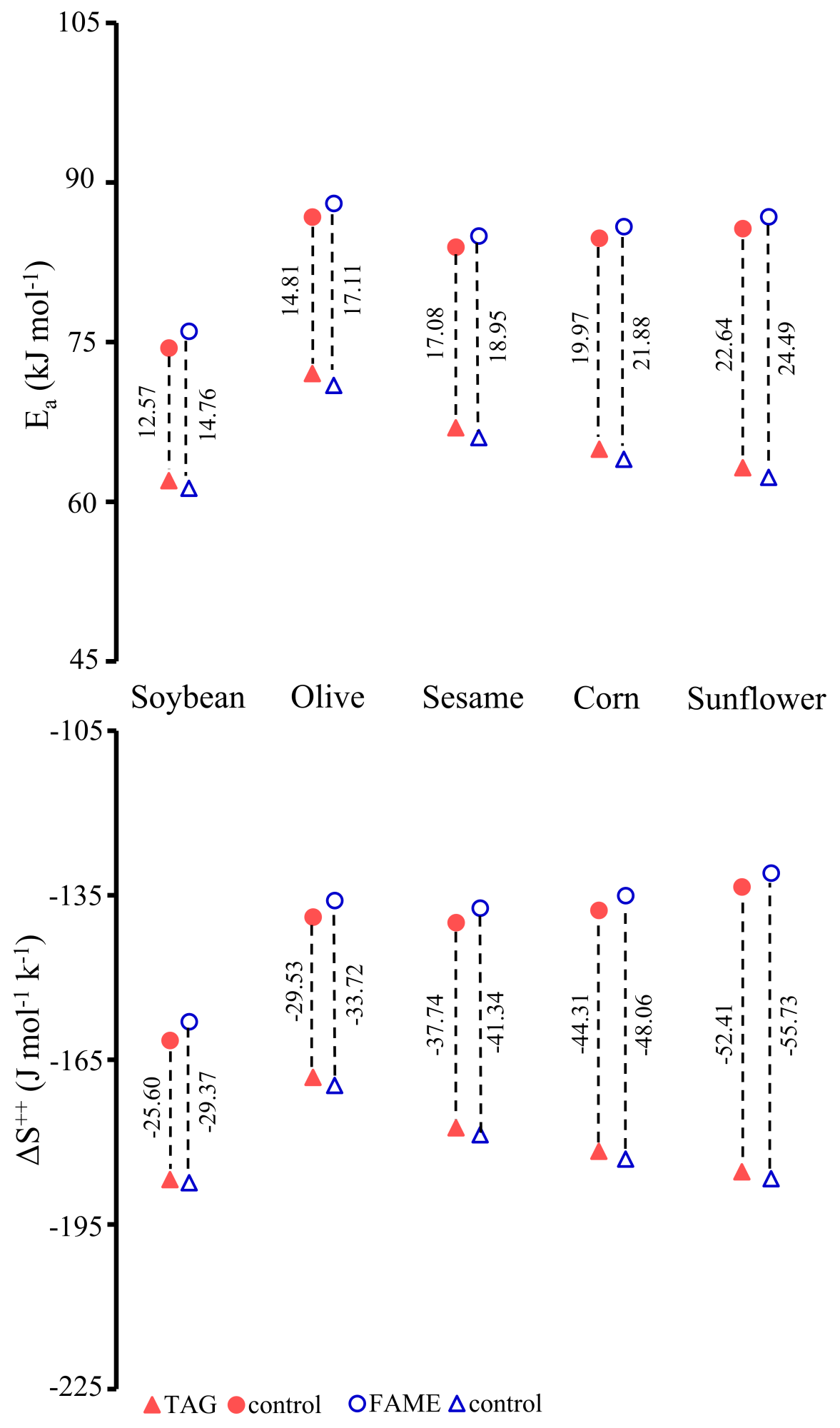




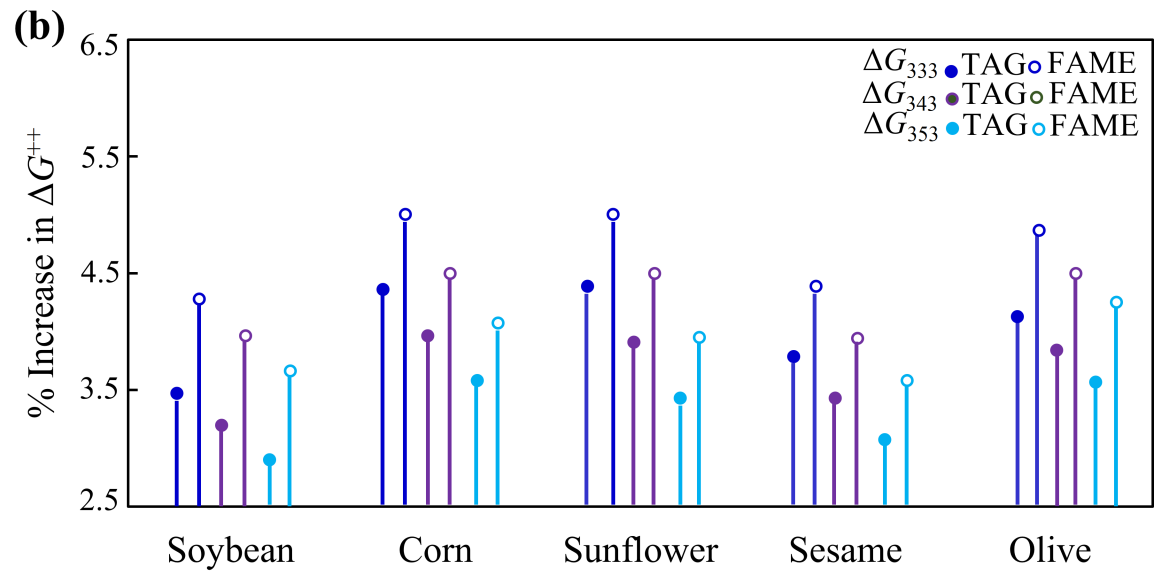

(a)

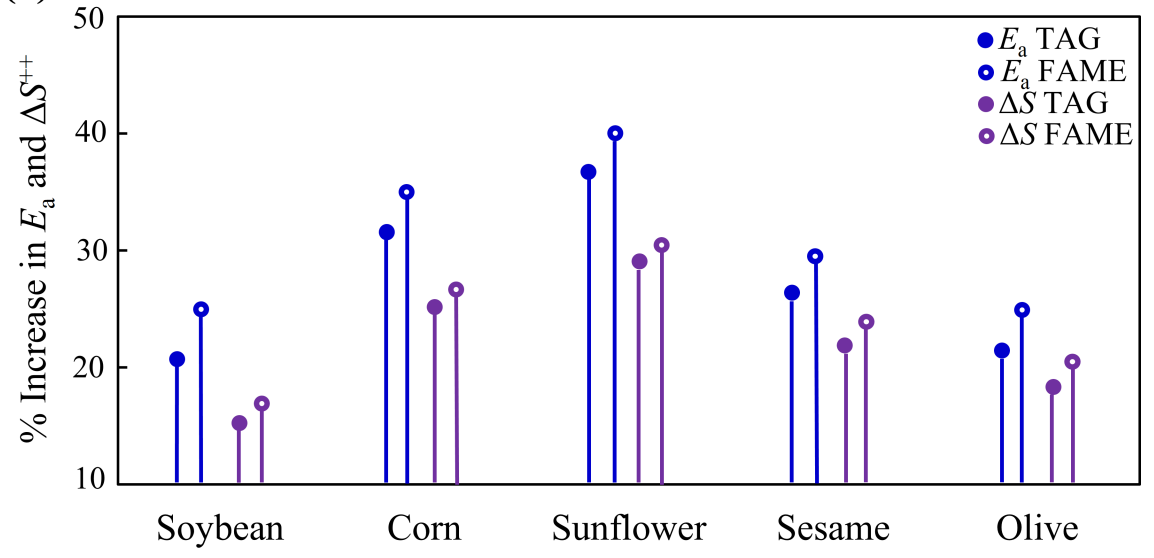



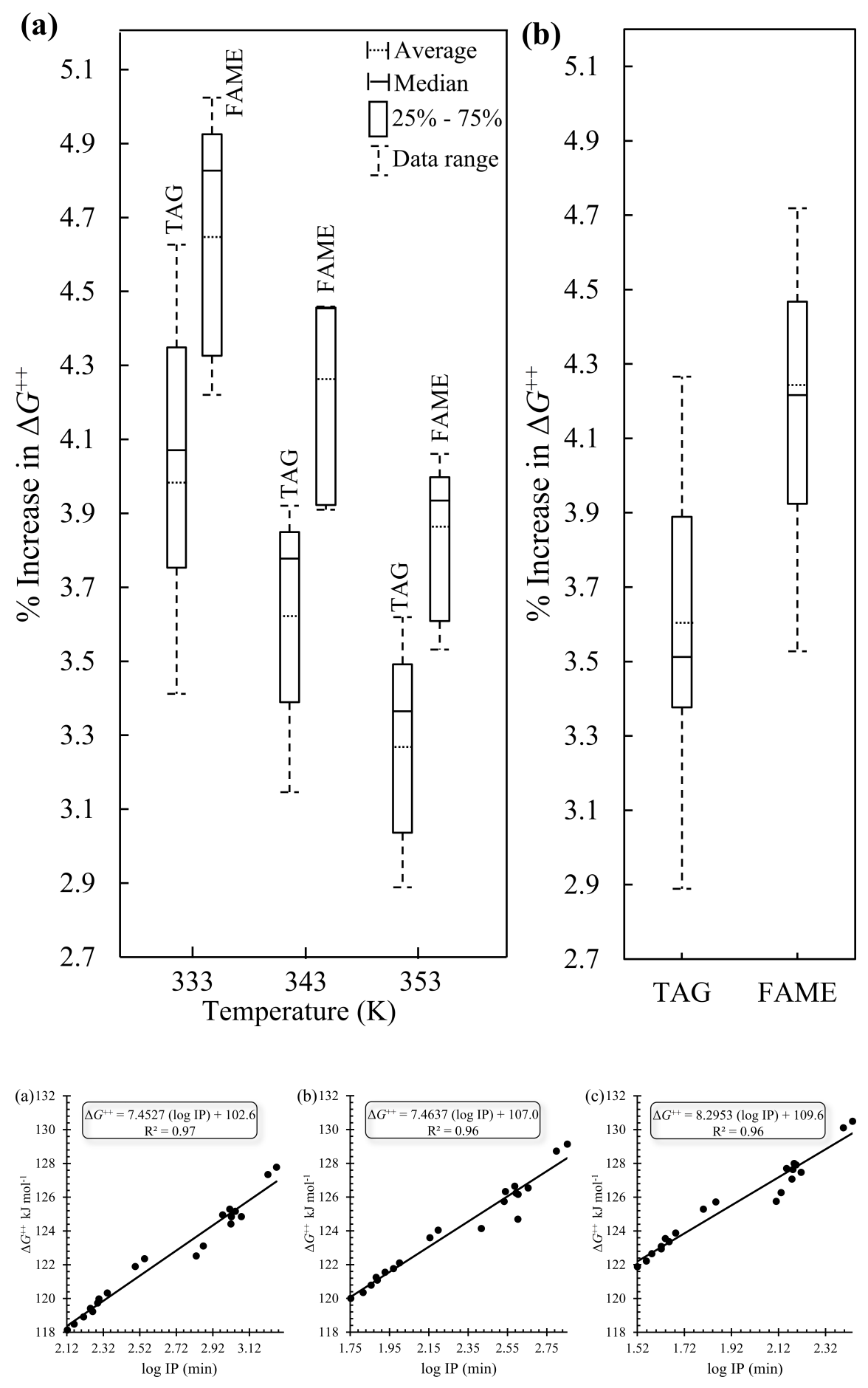

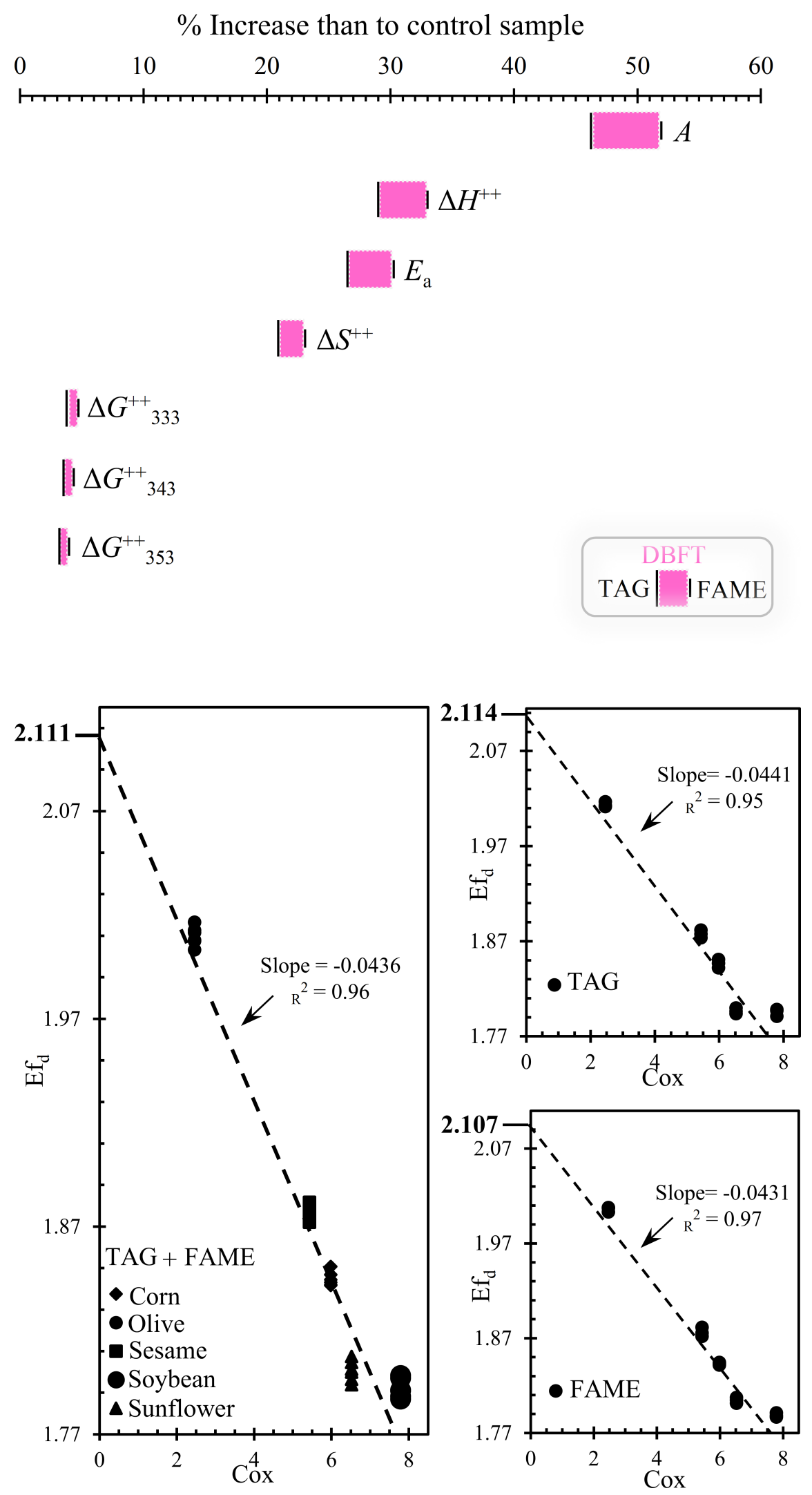